\title{
PATRIMONIALIZACIÓN Y ARQUEOLOGÍA MUlTiCUltural EN SAN PEDRO DE ATACAMA (NORTE DE CHILE)
}

\author{
Patricia Ayala Rocabado ${ }^{1}$
}

\section{* Introducción}

\section{Resumen}

En este artículo abordo el multiculturalismo neoliberal implementado en Chile como un arte de gobierno étnico, en cuya producción

participan activamente la arqueología y los arqueólogos en tanto agentes colectivos e individuales de la patrimonialización. Presento los resultados de una etnografía de los discursos y las prácticas a través de las cuales el Estado chileno se representa como multicultural y como una nación pluriétnica. Proceso en el cual autentifica, legitima y patrimonializa la cultura indígena, utilizando y produciendo para ello la autoridad científica. Entrego además una "etnografía arqueológica" de las prácticas y discursos de la arqueología atacameña y su relación con el multiculturalismo. Para ello considero una etnografía multisituada que resalta la articulación y contemporaneidad de procesos locales, regionales, nacionales y transnacionales, centrándome en la primera década del siglo XXI.

Palabras claves: multiculturalismo - neoliberalismo - patrimonialización nacionalización - arqueología.

In this paper I address the neoliberal multiculturalism in Chile as the government of the ethnic, in which production are actively involved the archeology and archaeologists as collective and individual agents of the patrimonialization. I present the results of an ethnography of discourses and practices through which the Chilean State is represented as a multicultural and multiethnic nation. A process in which the State authenticates and legitimizes the indigenous culture and defines it as national heritage, using and producing scientific authority. I also present an "archaeological ethnography" of the practices and discourses of archeology in Atacama and its relationship to multicultural policies. I consider a multi-located ethnography that highlights the contemporary articulation of local, regional, national and transnational processes. This study focuses on the first decade of the 21st century.

Key words: multiculturalism - neoliberalism - patrimonialization nationalization - archaeology.

Recibido: septiembre 2013. Aceptado: junio 2014.
Este artículo es una síntesis de algunas de las conclusiones más relevantes de mi tesis doctoral. Investigación en la cual estudié el multiculturalismo neoliberal implementado en Chile desde la década de los noventa como un arte de gobierno étnico, en cuya producción participan activamente la arqueología y los arqueólogos, en tanto agentes colectivos e individuales de la patrimonialización, espacio en el cual disputan distintos tipos de capital con agentes estatales, indígenas, agencias multilaterales y cientistas sociales. Realicé una etnografía de los discursos y las prácticas a través de las cuales el Estado chileno se representa como multicultural y se construye como nación pluriétnica, autentificando, legitimando y patrimonializando la cultura indígena mediante procedimientos legales y ritualizaciones, así como utilizando y produciendo para ello la autoridad científica. Asimismo, hice una "etnografía arqueológica" de las prácticas y construcciones discursivas de la arqueología atacameña y su relación con este nuevo arte de gobierno, poniendo en tela de juicio la supuesta autonomía del campo científico. Considerando que la patrimonialización y la arqueología multicultural se articulan con procesos locales, regionales, nacionales y transnacionales, adopté una etnografía multisituada resaltando la articulación y contemporaneidad de los diferentes niveles de análisis. El período estudiado abarca la primera década del siglo XXI, aunque considera una perspectiva histórica de los procesos investigados.

En el primer subtítulo abordo la perspectiva teórica que adopté para estudiar el multiculturalismo y sus vínculos

1 Dirección postal: 1 Higgins Terrace, Bar Harbor, Maine 04609, USA. Email: rayala@ucn.cl 
con el neoliberalismo y el nacionalismo, además de discutir la definición de Estado y las corrientes arqueológicas que guiaron mi análisis. En el segundo, entrego los principales resultados de las etnografías realizadas, articulando la información analizada con el marco teórico y conceptos antes discutidos. En el tercero, presento una reflexión autobiográfica de mi práctica arqueológica en San Pedro de Atacama (II Región, norte de Chile).

\section{* Multiculturalismo, neoliberalismo Y NACIONALISMO}

Con el advenimiento del multiculturalismo a finales de la década de los ochenta a nivel mundial se produjeron una serie de cambios al interior de la arqueología, ya que después de un intenso y largo debate para justificarla y posesionarla como ciencia, es decir, definir qué es la arqueología, se inició una discusión enfocada en los procesos y las condiciones de producción de su discurso. Así se instalan en el campo científico de la arqueología las teorías críticas, enriquecidas por la filosofía y la sociología de las ciencias, así como por los aportes de la antropología y los estudios culturales. En este contexto, reproduciendo lo que sucedía a nivel global, los arqueólogos celebraron la llegada del multiculturalismo como una salida al etnocentrismo y logocentrismo, además de promover "the return of the native" y el reconocimiento de sus derechos y demandas culturales (Shank y Tilley 1987; Hodder 1991). Como consecuencia y a la vez produciendo este nuevo escenario político, se abrió el debate sobre la democratización del conocimiento, el pluralismo, la multivocalidad, la inclusión de otras voces, la reflexión disciplinaria, la autoridad, las relaciones de poder, la representación y la repatriación a nivel mundial.

En Chile, si bien esta discusión se desarrolló más tardíamente que en los países anglosajones y en otras realidades sudamericanas, el multiculturalismo también conllevó la diversificación de las relaciones entre arqueólogos e indígenas, la apertura de nuevos espacios de participación local, la ampliación de los circuitos de difusión del discurso científico, la respuesta a una serie de demandas indígenas vinculadas con el patrimonio arqueológico y la inserción a proyectos de impacto ambiental (Ayala 2007 y 2008). Situación vinculada con una serie de innovaciones institucionales y legales a partir de las cuales el Estado chileno reconocía la diversidad cultural de la nación y comenzaba a reconstruirse como nación democrática y pluricultural post dictadura (Schild 2000; Paley 2001; Boccara 2007; Bolados 2010; Boccara y Bolados 2010).

Sin embargo, como intentaré demostrar en este trabajo, una evaluación crítica de las relaciones y disputas de poder en los espacios de participación abiertos por el multiculturalismo en Chile, deja en evidencia que la arqueología, en particular la desarrollada en la región atacameña, continúa reproduciendo relaciones coloniales de dominación, aunque ya no desde la negación y exclusión sino desde la inclusión. Su poder y autoridad como discurso experto en la construcción, autentificación y legitimación de identidades -étnicas y nacionales- no sólo no ha cambiado de lugar sino que se ha fortalecido. Lo cual es una consecuencia de su rol activo en la estructuración del campo burocrático (sensu Bourdieu 1997) ${ }^{2}$ desde donde se produce y representa al Estado multicultural, a la vez que éste último interviene directamente en la construcción de la arqueología. Situación que se vincula, además, con el monopolio de los enfoques culturalista y positivista en la arqueología chilena, a partir de los cuales no sólo se interpreta la "cultura material” sino que se genera una visión y división del mundo social en el cual se desarrolla esta disciplina. Las repercusiones de la autoridad que ejercen estas corrientes teóricas en el campo arqueológico, se han traducido en una visión esencializada de las diferencias culturales promovidas, producidas y gestionadas por el multiculturalismo. Así como se observan en la reafirmación de la cientificidad de la arqueología a través del refinamiento metodológico y tecnológico para estudiar/ producir/legitimar el pasado, la cultura y el territorio de las poblaciones indígenas.

\footnotetext{
2 La noción de campo se refiere al espacio de relaciones de fuerza entre los agentes que están suficientemente provistos de uno de los diferentes tipos de capital (cultural, social, político, simbólico y/o económico) para estar en disposición de dominar el campo correspondiente y cuyas luchas se intensifican todas las veces que se pone en tela de juicio el valor relativo de los diferentes tipos de capital; es decir, en particular, cuando están amenazados los equilibrios establecidos en el seno del campo de las instancias específicamente encargadas de la reproducción del campo de poder (Bourdieu 1997: 50-51).
} 
Esto se explica, entre otros factores, por la adopción en la arqueología atacameña de un enfoque teórico culturalista para comprender el multiculturalismo de Estado, a partir del cual se concibe la diferencia cultural como expresión de una realidad dada. Desde esta perspectiva, el régimen de verdad impuesto por la política de la diferencia, reproducido a su vez por la arqueología multicultural (sensu Gnecco 2008), genera una concepción de cultura similar a la que se tenía a principios del siglo XX, es decir, culturas separadas, entidades individualizadas, típicamente asociadas con "una gente", "una tribu", una "nación". Definición que hizo posible el estudio antropológico, la comparación cultural y la conceptualización del mundo como un mosaico de culturas, lo que sin duda recuerda el discurso de algunos agentes de la política indígena contemporánea. El posterior desarrollo de la idea de cultura como formando un sistema de significados sólo reforzó esta visión del mundo social. La esencialización y fijación de la diversidad cultural construida y legitimada por el multiculturalismo de Estado, desconoce que la identidad y la diferencia cultural están llegando a ser cada vez más desterritorializadas y que se ha producido un proceso de espacialización a través de las migraciones en masa y los flujos de culturas transnacionales del capitalismo tardío (Ferguson y Gupta 2005). En este escenario, estos autores advierten la necesidad de cuestionar la idea de que lo auténtico corresponde a lo "local" o a la "comunidad", entidades vista como simplemente dadas o naturales, ya que contrariamente a esto éstas son construidas por fuerzas del capital transnacional, el Estado y las poblaciones locales.

La actualización del pasado indígena en tanto patrimonio nacional en la era multicultural, también tiende a difundir un nuevo régimen de verdad sobre lo que es cultural, nacional y patrimonio y lo que no lo es. Según Briones la actual politización social de la cultura:

"tiende a retomar esa noción clásica del término según la cual la cultura es, fundamentalmente, lo que la gente hace....(pero) la cultura no se limita a lo que la gente hace y cómo lo hace ni a la dimensión política de la producción de prácticas y significados alternativos; más bien es un proceso social de significación que, en su mismo hacerse, va generado su propia metacultura... su propio "régimen de verdad" acerca de lo que es cultural y no lo es..."(Briones 2005b: 16).
Esta visión de corte culturalista se produce tanto en el campo burocrático como en el campo de la arqueología a través de la patrimonialización y los espacios interculturales abiertos por el multiculturalismo (Boccara 2007; Boccara y Ayala 2011). La noción de cultura/ patrimonio que se genera y legitima en estos contextos tiene la ventaja de fijar la cultura, materializarla, monumentalizarla, naturalizarla y restringirla sólo a lo que "la gente hace", así como a lo que es "declarado" como tal a través de un acto de nombramiento -legalque recae en el poder y autoridad del Estado. Lo cual se concretiza vía patrimonialización, entendida en esta investigacion como el mecanismo de apropiación, construcción, autentificación y legitimación de la diversidad cultural a favor de la historia del Estado-nación. Proceso en el cual los arqueólogos ejercen su poder y autoridad como expertos en la producción de las culturas, identidades y territorializaciones (étnica y nacional), lo cual es llevado a cabo a través de una consecución de actos de limpieza casi clínica (técnica) a través de la prospección, excavación, análisis, clasificación, interpretación y mapeo de sus sitios arqueológicos. Situación que pone en tela de juicio la autonomía, neutralidad y despolitización del campo arqueológico defendida por el enfoque positivista, toda vez que las prácticas y discursos arqueológicos son parte, producen y son producidos por los campos científico y burocrático a través de la patrimonialización.

Comprender cómo la cultura ha llegado a ser una categoría central en el discurso público y determinante en la construcción de las identidades sociales y políticas y, concomitantemente con ello, entender la conformación de la patrimonialización y la arqueología multicultural, requiere definir cómo entiendo el multiculturalismo. Para ello adopté la línea de pensamiento iniciada para el campo de la salud chilena por Guillaume Boccara (2007), quien retomando la teoría de la gubernamentalidad propuesta por Foucault (2006) y otras investigaciones antropológicas que la aplican, propone que el multiculturalismo es el gobierno de lo étnico. Es decir, una nueva forma de gubernamentalidad de tipo étnico que tiende a extender los mecanismos de intervención del Estado, así como a generar nuevas subjetividades, nuevos espacios de poder, nuevos campos de saber y nuevos mercados de bienes simbólicos y exóticos en los cuales agentes sociales de un nuevo tipo se enfrentan en torno a la definición de 
los principios legítimos de autentificación cultural y de visión y división del mundo social (Boccara 2007: 201).

Ahora bien, como lo planteó Charles Hale (2002) el multiculturalismo no puede ser comprendido sin su estrecha conexión con el neoliberalismo, ya que la premisa de que las luchas indígenas y las ideologías neoliberales son dos fenómenos opuestos entre sí es incorrecta, por lo cual definió esta relación como "multiculturalidad neoliberal". A través de la cual los propulsores de la doctrina neoliberal apoyan de modo proactivo una versión importante, si bien limitada, de los derechos culturales indígenas, como medio de resolver sus propios problemas y avanzar sus propias agendas políticas (Hale 2002: 288-289). Profundizando en estos vínculos se plantea que con el multiculturalismo se asienta una racionalidad neoliberal que tiende a responsabilizar a los agentes sociales, a tratar a las comunidades como pequeñas empresas, a generalizar las relaciones de mercado que llegan a ser unos elementos esenciales del tejido social, a flexibilizar y precarizar el mercado laboral y a someter la sociedad a la economía. Emerge en este contexto político la figura del "indio proyecto", del "cliente exótico" o del "market-citizen" (Schild 2000) que debe encontrar su lugar en los nuevos nichos de mercado.

"Moldeado de acuerdo a la imagen del homo economicus neoclásico, el indigena tiene que operar elecciones racionales. Las prácticas y representaciones indígenas se convierten en patrimonio, llegan a ser mercancías. Mercantilizada, patrimonializada y transfigurada, la "cultura" se convierte en un recurso escaso y obedece por consiguiente al principio de economicidad. Las elecciones culturales conllevan desde ahora un costo de oportunidad" (Boccara y Ayala 2011: 15).

El multiculturalismo neoliberal incita a los indígenas a ser emprendedores, a administrar y "marketear" sus productos y prácticas culturales como fuente de valor y de propiedades intelectuales. Mediante la patrimonialización se los estimula a ser gestores y administradores de sus sitios arqueológicos, a integrarlos al mercado turístico transnacional como bienes exóticos y símbolos de su autenticidad y legitimidad cultural. Proceso que a la vez repercute en la esencialización y diferenciación entre sus comunidades, las cuales en el caso atacameño se disputan la propiedad del patrimonio arqueológico listo para ser marketeado como emblema de su aboriginalidad y nacio- nalidad. El neoliberalismo como tecnología de gobierno extiende y disemina los valores del mercado a la política social y a las instituciones. La universalidad con la que se ha impuesto la lógica neoliberal en sectores privilegiados para el desarrollo capitalista, donde se enfrentan los intereses transnacionales con las demandas indígenas, como la región atacameña, ha llevado a Bolados (2010) a plantear que en Chile y otros países de la región, más que un multiculturalismo neoliberal es un neoliberalismo multicultural. "Este se caracterizaría principalmente por representar más que una versión limitada del multiculturalismo, una versión extendida del neoliberalismo hacia campos socioculturales antes ignorados" (Bolados 2010: 16). Es precisamente en estos espacios de disputa por los recursos culturales y naturales donde los arqueólogos intervienen como consultores en el mercado de la arqueología de impacto ambiental que "rescata" y "pone en valor" el pasado indígena.

En este cambio en la forma de gobierno se quiere integrar a las poblaciones indígenas al proceso de democratización y modernización, a la vez que desviarlas de sus excesos radicales. Para Hale (2002: 303-304) el multiculturalismo neoliberal consistiría en "domesticar y redirigir la abundante energía política que muestra el activismo de los derechos culturales en vez de oponerse directamente a él". Lo que implica separar las demandas indígenas aceptables de las consideradas inapropiadas, reconociendo a las primeras y cerrándole el paso a las otras, gestionando así el multiculturalismo aunque eliminando su impronta radical o amenazadora. En este contexto, esta gobernamentalidad se ejerce a través del "indio permitido", en circunstancias que la tradición indígena a la que se quiere hacer partícipe debe ser funcional a los nuevos proyectos de etnodesarrollo, es decir, que debe ser reconstruida, reinventada y refuncionalizada a la imagen y semejanza del multiculturalismo de Estado.

Se activan entonces categorías similares a las popularizadas por la antropología anglosajona (el buen salvaje y el mal salvaje), aunque en este caso las representaciones sociales del otro son las del "indio permitido" versus el "indio radical insurreccionario". Para Hale y Millaman (2005), el primero correspondería a un sujeto colectivo portador de derecho, un espacio negociado con prerrogativas, pero también con claros límites que hacen po- 
sible un gobierno efectivo. Otro binomio en el orden de las representaciones, vinculado también con el anterior, resultaría de dos ejercicios de poder diferencial en la era neoliberal y multicultural del capitalismo global: el "cliente exótico" o "indígena proyecto" versus el "terrorista antimoderno". De acuerdo a ello, coexisten dos lógicas políticas de tratamiento de la cuestión socioétnica en Chile (Boccara y Bolados 2010). Una lógica de la democracia dialógica que opera a través de dispositivos de poder participativo e intercultural de tratamiento de la diversidad cultural y de la autentificación en términos ahistóricos y esencialistas de la cultura y comunidad indígena legítima. Paralelamente a la cual se da otra de un estado de excepción permanente que se materializa mediante la represión bruta vía sus aparatos de seguridad, participando de la invisibilización de los mecanismos socio-históricos de producción de la diferencia cultural y de las relaciones de jerarquía y dominación entre los grupos sociales (Boccara y Bolados 2010: 684).

Considerando los espacios y mecanismos de autentificación y legitimación abiertos a través de la patrimonialización, se distingue otra representación diferenciada, la del "indio auténtico" versus el "indio inauténtico", el primero de los cuales sería el portador de una cultura tradicional deshistorizada y territorializada, capaz de probar científicamente su continuidad histórica de larga data y con ello legitimarse ante el Estado. Se trataría de sujetos conocedores de su historia, su pasado y su patrimonio a través del discurso legitimado de la ciencia, es decir, el "nativo histórico" asociado a su vez con el "nativo ecológico" que definen los movimientos verdes (Gnecco 2008). En este juego de representaciones sociales el "indio auténtico" es el que conserva su cultura, el que utiliza su vestimenta tradicional y realiza "ritos de autenticidad" para ceñirse a los cánones del multiculturalismo neoliberal. En cambio, aquellos que se aventuran a estar con poncho y celular en mano, a desear casas "como las de la ciudad" o a bailar música tecno en vez de tinkus, son calificados como "indios inauténticos", más aún si no pueden probar, vía fechados absolutos, su continuidad histórico cultural.

Es en el campo etnoburocrático donde operan estos mecanismos de legitimación, autentificación, representación y consagración de nuevos agentes sociales cuyo objetivo es saber quien está autorizado para decir que es un indígena y cual es la cultura indígena auténtica, a la vez que se impone una nueva normativa o legalidad con respecto del ejercicio legal de la "indigeneidad". Dichos mecanismos de legitimación y normalización tienden a producir efectos de estandarización de las culturas indígenas, de profesionalización de sus portadores y de delegación del poder de representación político. Con la comunidad y la cultura como nuevos objetos de gobierno el multiculturalismo investiga la realidad indígena a través de profesionales de las ciencias sociales legitimados por el poder del Estado. Por medio de encuestas, censos, reuniones, focus groups, entrevistas y sondeos, se busca elaborar una imagen fidedigna de la sociedad y de la cultura de las poblaciones indígenas que habitan el territorio nacional. Como se discutirá en este trabajo, los arqueólogos multiculturales, en posesión de un capital social y simbólico destacado en el campo etnoburocrático, también estudian y producen una imagen "hyper real" de la cultura, el pasado y el territorio indígena. A través del CMN y la Corporación Nacional de Desarrollo Indígena (CONADI en adelante) se solicitan los servicios de consultoras para elaborar catastros de sitios, proyectos de puesta en valor, conservación y protección, cursos de capacitación, rescates y salvatajes. Así la arqueología multicultural contribuye a construir una versión estándar y esencializada de la cultura indígena, la cual también se produce a través de la definición de una temporalidad lineal de larga data en la construcción del pasado indígena. Proceso que también conlleva una reapropiación indígena de su patrimonio en función de una esencialización y naturalización de su pasado y su cultura, así como de la nacionalización de los mecanismos de identificación en referencia a una memoria patrimonializada (Ayala 2008).

Siguiendo la lógica de la democracia neoliberal post dictadura se han abierto una serie de escenarios de participación mediante los cuales el Estado se visibiliza, concretiza y construye (Schild 2000; Paley 2001). A través de la patrimonialización el Estado no sólo se pone en escena, sino que se legitima y produce por medio de prácticas y representaciones cotidianas. Lo cual se relaciona a su vez con el acto de nombramiento, definición y clasificación de la cultura patrimonializada y con la producción de una serie de signos y rituales que representan el poder simbólico del Estado. Proceso mediante el cual también produce lo indígena a través 
de su ritualizacion pública en reuniones, celebraciones, mesas de diálogo y la declaración oficial de lo que es el patrimonio indígena.

Los nuevos métodos de intervención estatal a través de los cuales se gobierna a los indígenas, requieren la presencia en terreno de los agentes encargados de la política multicultural, quienes incitan a la población local a actuar, a participar, a expresar sus opiniones, a pensar en etnodesarrollarse. Se busca establecer una suerte de "partnership" entre las comunidades indígenas y las distintas agencias estatales y para-estatales. En lugar de intervenir desde el exterior, de manera discrecional o asistencialista, a través de la patrimonialización se procura involucrar a los indígenas en su propio etnodesarrollo con la ejecución de proyectos de puesta en valor, de rescate cultural, de rescate de la lengua veráncula, de la música autóctona y de los bailes tradicionales, buscando así que los indígenas "se ayuden a si mismos" para entrar al mercado cultural de bienes exóticos. Y como corolario de este proceso, así como el Estado reconoce sus "demandas aceptables" en temática patrimonial, responsabiliza a los indígenas por el cuidado de los sitios arqueológicos que administran y por la ejecución de una multiplicidad de proyectos de rescate.

Ahora bien, la implementación de este nuevo arte de gobierno no se hace sin tensiones y contradicciones. Las nuevas posibilidades políticas no sólo radican en grandes oposiciones sino que en los intersticios de las estructuras de poder emergentes y en los nuevos espacios políticos y sociales en construcción (Boccara y Bolados 2010: 683-684). Se trata de los efectos no esperados o deseados del multiculturalismo, ya que los indígenas no se limitan a ser objetos de gobierno y etnodesarrollo. A través de la patrimonialización cuestionan al Estado multicultural desde adentro y participan de las nuevas luchas por la definición, clasificación y propiedad de su patrimonio. Asimismo, se aprovechan del proceso de profesionalización indigena para apropiarse del discurso patrimonial y científico y usarlo en sus luchas políticas contra el Estado y los arqueólogos, así como para ocupar espacios antes vetados, como los museos, y conseguir posesionar viejas y nuevas demandas, además de buscar el reconocimiento del conocimiento local en igualdad de condiciones con el científico. La politización de la cultura y el nuevo régimen de verdad multicultural acerca de lo que es cultural, nacional y patrimonio, es un proceso disputado de construcción de significados, que "por su carácter siempre abierto a la contestación y a la disputa ninguna hegemonía cierra perfectamente el circulo" (Briones 2005b: 18).

Paralelamente a lo anterior, el multiculturalismo neoliberal contribuye al asentamiento de un nacionalismo renovado a partir del cual se re-imagina una comunidad nacional diferenciada. Considerando que el nacionalismo es el programa a través del cual se crean las naciones y que existe previamente a la formación de las mismas (Hobsbawm 1991), en esta nueva era de gobierno, a través de la patrimonialización se han activado diferentes dispositivos estatales orientados a la construcción de la nueva nación chilena. Tal como lo afirma Gellner (1983) la existencia de la nación está supeditada a una definición previa y asumida de Estado, ya que el nacionalismo sólo emerge en situaciones en las que la existencia de este último se da ya por supuesta. Coincidentemente con ello Hobswam (1991) afirma que la nación es una entidad social sólo en la medida en que se refiere a cierta clase de estado territorial moderno, por lo que de nada sirve hablar de nación y de nacionalidad excepto en la medida en que ambas se refieren a él.

La congruencia entre el Estado multicultural neoliberal y una nueva forma de nacionalismo diferencialista, no sólo incide en el modo como operan y circulan los otros internos y externos, sino también en la re-territorialización del Estado-nación chileno. En este contexto, las culturas e historias indígenas se encuentran patrimonializadas tanto a través de actos y procesos legales como de estudios arqueológicos que construyen una cartografía del patrimonio nacional. Nuevas fronteras se dibujan entre los indios que han sido siempre parte de la nación y los otros radicalmente otros, los indios extranjeros, inmigrantes ilegales de la era proto-nacional o pre-política (Boccara y Ayala 2011). En palabras de Briones (2005b: 23).

“...si la Nación como Estado opera como territorio simbólico contra la cual se recortan y en el cual circulan distintos tipos de "otros internos", las geografias estatales de inclusión -que son simultáneamente geografías de exclusión- remiten a la cartografía hegemónica que fija altitudes y latitudes diferenciales para su instalación, distribución y circulación. Entre otras cosas, estas geo- 
grafias de inclusión/exclusión intentan inscribir por anticipado en el "sentido de pertenencia" de esos contingentes la textura de las demandas que vayan a realizar".

Si bien se ha discutido la complejidad de definir la nación, Hobsbawm (1992) resalta el carácter de artefacto, de invención e ingeniería social que interviene en su construcción, en tanto para Anderson (2007) el énfasis esta puesto en su creación y en el estilo con el que son imaginadas. La re-imaginación de la nación chilena en la era del multiculturalismo neoliberal ha activado un proceso de invención de una tradición nacional, lo cual conlleva a su vez un "proceso de formalización y ritualización, caracterizado por la referencia al pasado, aunque sólo sea al imponer la repetición" (Hobsbawm y Ranger 2002: 10). Desde la promulgación de la Ley Indígena se integró a las poblaciones indígenas como parte de la nación chilena, lo que no sólo ha repercutido en re-imaginarse como nación pluriétnica sino en reinventarse a través de una temporalidad lineal que se impone a los otros internos vía patrimonialización. A través del poder simbólico del Estado multicultural se crean nuevos símbolos, concepciones y ritualizaciones asociadas a este nuevo nacionalismo diferencialista.

Si la nueva nación multicultural no tiene existencia empírica tanto como imaginada, de ahí la urgencia estatal por reafirmar la autoridad de la arqueología cuyos vínculos con el nacionalismo y la construcción de una identidad nacional han sido ampliamente estudiados (p.e. Trigger 1984; Khol 1998; Díaz-Andreu 2001; Gnecco 2002 y 2008; Londoño 2003). Al respecto, Gupta y Ferguson (1997: 14) advierten que el tema de la identidad ha sido a menudo enfocado de una manera que tiende a disminuir el rol de los procesos de legitimación y autentificación. Por lo que restaurar esta preocupación en el centro de la discusión sobre la identidad podría permitir indagar por qué ciertos tipos de identidades llegan a ser sobresalientes en un momento histórico particular, así como por qué algunas marcas de distinción y diferencia no forman las bases de una identidad. En este contexto, las identidades nacionales necesitan ser entendidas en relación a otras entidades subnacionales y supranacionales y probablemente aún en contraste con formas de imaginación de comunidad que no están territorialmente basadas.
En Chile, paralelamente a los aportes que buscan desnaturalizar las concepciones de la cultura que se producen a través de la gubernamentalidad en el campo de la salud intercultural (p.e. Boccara 2007; Boccara y Bolados 2010) existe un verdadero silencio acerca cuales son las nociones de cultura/patrimonio e identidad que se construyen a través de la patrimonialización de los últimos veinte años. Así como cuál es la noción de patrimonio indígena que se impone a través de las instituciones estatales y sus ritualizaciones. También se observa una ausencia de trabajos que exploren cómo y a través de qué mecanismos la arqueología participa en la fábrica del multiculturalismo de Estado. Destacando también el vacío de investigaciones sobre las repercusiones de la política de la diferencia en el campo arqueológico propiamente tal, no sólo en términos de los programas y espacios de participación indígena sino también en la construcción cotidiana de sus prácticas y discursos. Tampoco se cuenta con estudios referidos a los procesos y espacios de autentificación y legitimación estatal en los cuales la arqueología y la patrimonialización ocupan un papel destacado en los procesos de etnicidad, nacionalización y territorialización.

Si bien se cuenta con escasas excepciones (p.e. Troncoso et. al. 2008; Romero 2009; Ayala 2008), la arqueología chilena no ha realizado un trabajo reflexivo sobre su papel en las políticas de la memoria, sus relaciones con el poder estatal, el colonialismo, el nacionalismo y el multiculturalismo, su rol en la deslegitimación de los saberes y los discursos indígenas, su imposición de una periodización histórica, su reafirmación del lugar de enunciación científico y sus representaciones del otro. Por ello exploré lineas de trabajo que, desde la antropología y la arqueología, cuestionaran la neutralidad científica y la despolitización de estas disciplinas. En este contexto, adopté y desarrollé la definición planteada por Cristobal Gnecco (2008) sobre la arqueología multicultural, la cual recoge una perspectiva crítica de las trampas del multiculturalismo. Para este investigador, este tipo de arqueología es una práctica disciplinaria interesada en alcanzar audiencias más amplias, entrenar actores locales en investigaciones de campo y usar visiones históricas no académicas en sus interpretaciones. Es una arqueología acomodada a los mandatos de la lógica multicultural sin renunciar a sus privilegios (Gnecco 2008: 19). 
Paralelamente a esto, retomando las perspectivas que cuestionan la visión del Estado como un ente abstracto, monolítico y siempre dado, separado de la economía y la sociedad (Mitchell 2006: 173), analizé el Estado multicultural en sus formas cotidianas, en las prácticas y discursos de agentes e institucionales emergentes, en su legalidad, en los espacios y programas que produce y dónde se produce, en sus conexiones y efectos locales, regionales e internacionales, en sus rituales y representaciones. Lo que implicó "desagregar el Estado en la multiplicidad de sus operaciones discretas, en sus procedimientos, representaciones" y ritualizaciones (Blom Hansen y Steputtat 2001, en Boccara 2007). En otras palabras, se trató de desnaturalizar al Estado multicultural neoliberal, dar cuenta de cómo se conceptualiza e implementa desde varios sitios etnográficos de la patrimonialización: el CMN y su Programa de Asuntos Indígenas y el Día del Patrimonio, además de los programas patrimoniales de la CONADI y el Programa Orígenes. A lo que se sumó el Instituto de Investigaciones Arqueológicas y Museo (IIAM en adelante), la Escuela Andina, el Programa de retiro de los cuerpos de la exhibición. Considerando que el Estado se construye y materializa a través de la patrimonialización a la vez que ésta produce al Estado, este proceso se constituye en un espacio social privilegiado para desnaturalizarlo, toda vez que ocupa un lugar central en la generación de procedimientos por medio de los cuales el Estado se nos impone como natural (Bourdieu 1997). Asimismo, de manera coherente con la perspectiva de análisis del multiculturalismo que adopté, se quiso cuestionar las posiciones que sostienen el retiro del Estado como parte de las políticas neoliberales, sosteniendo más bien su reconfiguración en este contexto político.

Seguí la perspectiva de Bourdieu (1997) en términos de destacar las dimensiones productivas y generativas del poder del Estado en su forma gubernamental. Por ello concebí al Estado como el resultado de un proceso de concentración de diferentes tipos de capital, capital de fuerza física o de instrumentos de coerción, capital económico, capital cultural, capital simbólico, concentración que, en tanto que tal, lo convierte en poseedor de una especie de metacapital, otorgando poder sobre las demás clases de capital y sobre sus poseedores. Según este sociólogo, esta concentración de diferentes especies de capital (que va pareja con la elaboración de los diferentes campos correspondientes) conduce en efecto a la emergencia de un capital específico, propiamente estatal, que permite al Estado ejercer un poder sobre los diferentes campos y sobre los diferentes tipos particulares de capital (Bourdieu 1997: 99-100).3 Como se verá más adelante, desde sus inicios la patrimonialización ha formado parte del campo burocrático del Estado y desde su reconfiguración en la era multicultural participa activamente en la estructuración del "campo intercultural" (Boccara 2007), en cuyo seno nuevos agentes, en posesión de diferentes tipos de capital, se enfrentan con respecto a los procedimientos de legitimación, autentificación y de consagración para finalmente definir "quien tiene la autoridad para decir que es un indígena" y "en que consiste la cultura indígena auténtica". Los arqueólogos también se han constituido en agentes del campo etnoburocrático, ya que dotados de un capital social y simbólico legitimado por el Estado, forman parte de este proceso de legitimación y autentificación de las diferencias culturales. A la vez que como agentes colectivos e individuales del campo científico disputan el monopolio de la autoridad científica.

Para el estudio de la arqueológica atacameña abordé las propuestas de las "arqueologías reflexivas"4 que, recogiendo los planteamientos de Foucault (1992) y los aportes de la sociología de las ciencias (Bourdieu 1997), se focalizan en los procesos y condiciones de producción del discurso y la práctica arqueológica (p.e. Watkins 2000; Zimmermann 2001; Gnecco 2002 y 2008; Haber 2004; Atalay 2006; Lilley 2008; Preucel y Cipolla 2008). Para ello me centré en el binomio saber/poder arqueológico evaluando sus vínculos con el colonialismo, nacionalismo y el multiculturalismo. Esto lo hice analizando el papel de la arqueología en la conformación, autentificación y legitimación de identidades (étnicas y nacionales), así como en la producción, definición, ad-

\footnotetext{
3 La elaboración del Estado va aparejada con la elaboración del campo de poder entendido como el espacio de juego dentro del cual poseedores de capital (de diferentes tipos) luchan particularmente por el poder sobre el Estado, es decir sobre el capital estatal que da poder sobre las diferentes especial de capital y sobre su reproducción (particularmente a través de la institución escolar) (Bourdieu 1997).

4 Este concepto se toma inspirado en la noción de sociología reflexiva de "An invitation to reflexive sociology" de Bourdieu y Wacquant (1992).
} 
ministración y legislación del patrimonio. Continuando una investigación previa (Ayala 2008) analicé las relaciones entre arqueólogos e indígenas atravesadas por la noción de participación promovida por el multiculturalismo. De este modo realicé una "etnografía arqueológica" (Castañeda y Mathew 2008) cuyo objeto de estudio más que el otro indígena es la arqueología misma, es decir, cómo trabaja y como se construye y es construida a través de sus prácticas y discursos. Esto implicó un posicionamiento de mi parte con las "arqueologías reflexivas", en términos de desnaturalizar la práctica arqueológica, desenmascar su proceso y condiciones de producción, reflexionar sobre las asimetrías sociales y económicas que la originaron y la siguen produciendo, cuestionar su autoridad científica y lugar de enunciación, concebirla como el estudio del poder y no sólo del estudio del pasado, es decir, hacer una arqueología "de otra manera”. Como se verá posteriormente, mi participación activa en la producción de la arqueología atacameña conllevó realizar un proceso auto-reflexivo sobre mi práctica profesional en aquellos espacios abiertos por la patrimonialización multicultural al interior del IIAM, los cuales coordiné y aporté a construir desde el poder y autoridad otorgado por el título, adjudicado por otros colegas y dicha institución, como "experta en las relaciones con las comunidades indígenas".

\section{* Nacionalizar y territorializar a través DE LA PATRIMONIALIZACIÓN}

Históricamente se puede situar los inicios de la patrimonialización a principios del siglo XX ya que en 1925 , con la promulgación del Decreto de Ley $\mathrm{N}^{\circ}$ 651, el Estado chileno comenzó a producir y definir categorías específicas de Monumentos Nacionales, así como creó el CMN y le asignó atribuciones para su cuidado y protección. Sin embargo, su funcionamiento fue irregular y se realizaron contadas declaraciones, aunque destaca el temprano nombramiento de la Isla de Pascua (1935) como Monumento Nacional por la necesidad de definir problemas de soberanía. ${ }^{5}$ Lo cual puede considerarse

5 En las Actas de ese año se plantea: "Isla de Pascua es uno de los bienes que más requiere esa declaración como se ha comprobado con el despojo que se ha sufrido recientemente y con el parecer del Sr. Auditor General de la Armada de que no pueden enviarse como el primer ejemplo de apropiación estatal del patrimonio y territorio indígena a través de una patrimonialización en ciernes. Paralelamente, se comienza a apoyar y financiar investigaciones arqueológicas en territorios conflictivos, como el norte y sur del país donde, por un lado, se producía un proceso de "chilenización" post Guerra del Pacífico y, por otro, se continuaba con la "pacificación de la araucania". Con la publicación del libro de José Toribio Medina, "Los aborígenes de Chile", se fundó lo que se constituiría en una arqueología nacionalista, paralelamente a lo cual se desarrolló una arqueología colonialista de la mano de investigadores extranjeros, como Uhle, quien fue contratado por el gobierno chileno para realizar excavaciones en el norte del país (Troncoso et al. 2008; Ayala 2007 y 2008). Si bien desde una ideología asimilacionista se negaba a las poblaciones indígenas, a las que se consideraba en proceso de desaparición o extinción, el proyecto nacionalizador requería de una historia que abarcara los orígenes prehispánicos de los habitantes de esos territorios. Las interpretaciones étnicas y culturalista de Uhle y su definición de lo "atacameño" para tiempos prehispánicos, permitieron preterizar y territorializar a las poblaciones indígenas, aportando así a la construcción de un Estado-nación culturalmente homogéneo y de matriz blanco-europea. A lo que contribuirán posteriormente Latcham, Oyarzún y Guevara con sus aportes en la ordenación cronológica, espacial y cultural de la prehistoria chilena y de los grupos indígenas que habitaban el territorio nacional. Todo lo cual ocurría en un contexto de incremento de las instituciones museales y culturales en el país, como el Museo de Etnología y Antropología (1912) que se sumaban a la temprana fundación de la Biblioteca Nacional (1813), del Museo Nacional (1830) y de la Universidad de Chile (1842).

La arqueología como disciplina comenzó su institucionalización en las décadas de los cuarenta y cincuenta, mayormente a través de estudios llevados a cabo por el Museo de Historia Natural, el Museo Arqueológico de la Serena y el Museo de San Pedro de Atacama, cuyos investigadores tenían diferentes trayectorias influenciadas por el empirismo y la historia cultural. Al igual

instrucciones de protección al Subdelegado Marítimo en la Isla mientras no se dé curso al Decreto correspondiente que le otorga la calidad de Monumento Histórico", página 2. 
que en los años anteriores, la patrimonialización desarrollada a través del CMN, si bien producía y legitimaba lo que se designaba como patrimonio de la nación, no implicaba una intervención del Estado en la regulación y control de las excavaciones arqueológicas y las colecciones acumuladas a partir de ellas, así como tampoco la definición de todo sitio arqueológico como Monumento Nacional. En este contexto desarrolla sus investigaciones Gustavo Le Paige en San Pedro de Atacama, quien practicó una arqueología colonialista a su llegada y con sus interpretaciones se sumó a la arqueología nacionalista posteriormente. La relevancia de su figura radica en que logró instalar en esta localidad, temprana y permanentemente, el poder científico representado por el museo que fundó, el cual reafirmaría su poder y autoridad a través de su integración a la Universidad Católica del Norte (1958). Lo que se sumó al proceso de modernización en el que se encontraba la población indígena, impulsado por las actividades mineras iniciadas a finales del siglo XIX. Fue Le Paige quien difundió la noción de "cultura atacameña" a través del museo y sus publicaciones y con ello contribuyó a la preterización y territorialización de los indígenas contemporáneos. Si bien defendió la tesis de continuidad cultural de larga data, concebía a la población indígena contemporánea en vías de desaparición y reprodujo relaciones de negación con los mismos (Ayala 2008). Estas se vinculan tanto a la violencia epistémica desplegada por la imposición del conocimiento científico sobre el local, como a la violencia simbólica o "experiencia traumática" (sensu Marcos 2010) producida por su excavación desmedida de tumbas y la conformación de una de las colecciones arqueológicas más grande del país. En particular, su colección de miles de cráneos recuerda la epistemología colonial de fragmentar partes del cuerpo y la documentación correspondiente en diferentes colecciones (Vezub 2009). Si bien Le Paige registró con rigor la procedencia de sus hallazgo y los mantuvo en una sola colección, la separación de cráneos y cuerpos remite a esa misma lógica colonial. Lo que se relaciona además a su afán de excavar como una forma de extirpación de idolatrías desde su posición de sacerdote/arqueólogo.

En la década de los setenta se produjeron cambios importantes en la patrimonialización ya que ésta comenzó a ser un espacio de mayor intervención del Estado, a la vez que este proceso aportó más significativamente en la construcción de la nación chilena. Se institucionalizó la enseñanza de la arqueología en diferentes universidades estatales y con ello se reafirmó su autoridad científica, poco antes de lo cual se iniciaron los Congresos Nacionales de Arqueología Chilena y se constituyó la Sociedad Chilena de Arqueología (1963). Paralelamente a esto se promulgó la Nueva Ley de Monumentos Nacionales (1970) y con ello el Estado comenzó a intervenir de manera directa en el control del patrimonio arqueológico, al declarar todos los sitios como Monumento Nacional, con lo cual no sólo impuso la propiedad estatal sobre los mismos sino que los nacionalizó. En este contexto, el poder simbólico del Estado se desplegó en el nombramiento de una mayor cantidad y variedad de declaratorias patrimoniales que en los años anteriores, aunque incomparable con la que se producirá en la era del multiculturalismo neoliberal. En una etapa de efervescencia cultural asume el poder político el gobierno socialista de Salvador Allende, durante el cual se aprueba la primera Ley Indígena $\left(n^{\circ} 17.729\right)$ del país, reconociendo la existencia de comunidades culturalmente diferenciadas, asumiendo una deuda histórica y entregando luces sobre su participación política. En este escenario, desde una postura política de izquierda se desarrolla la arqueología social, la cual coexiste con otra perspectiva más conservadora, científica y empirista de la arqueología (Troncoso et al. 2008). Las agendas académicas políticamente comprometidas se enmarcaron en una arqueología nacionalista que aportó en la construcción e imaginación de una comunidad nacional en tránsito al socialismo.

El golpe militar de 1973 cortó abruptamente con el desarrollo de la arqueología social y significó el cierre de dos carreras de arqueología, la cancelación de congresos nacionales y el control de la reflexión teórica en la disciplina. Asimismo, se importó y adoptó la Nueva Arqueología desde Estados Unidos, la cual paulatinamente se convirtió en un paradigma dominante, a la vez que las investigaciones se centraron en problemas cercanos a las ciencias naturales y se despolitizó el discurso. Desde el CMN el Estado ejerció su poder de nombramiento y se declararon más Monumentos Nacionales bajo la dictadura que en todos los años previos (Ayala 2008). Sin embargo, la intervención del Estado aún no se hacía sentir en la regulación y control de las excavaciones arqueológicas, aunque sí en el formato de las investigaciones a 
través de la creación del Fondo Nacional de Desarrollo Científico y Tecnológico (en adelante FONDECYT). La construcción de una nación chilena homogénea sin espacio para las poblaciones indígenas, a no ser por la exaltación de algunos guerreros "araucanos", se realizó paralelamente a la desarticulación de todo avance logrado por el gobierno socialista en las relaciones con las poblaciones indígenas. Al igual que en otros países de la región que tuvieron gobiernos dictatoriales, se inició la implementación de reformas económicas neoliberales cuyos primeros efectos significaron un nuevo y mayor empobrecimiento.

En San Pedro de Atacama el museo se convirtió en la salida a las desarticulaciones producidas por el golpe militar con el cierre de la carrera de arqueología en Antofagasta, ya que varios de sus profesionales fueron enviados a esta institución con la creación del IIAM en 1984. Desde una perspectiva despolitizada de la arqueología, incluso para quienes habían integrado la arqueología social años atrás, se renovó la exhibición del museo sin quebrar el dispositivo preterizador de exhibir los cuerpos humanos, lo cual apoyó el discurso negador de lo indígena del proyecto nacionalista. Así como se reprodujo y profundizó la epistemología colonial de fragmentar las colecciones al separar los contextos funerarios dejados por Le Paige de acuerdo a tipos de materialidad. Si bien las relaciones entre arqueólogos e indígenas siguieron siendo asimétricas, la permanencia en el tiempo de esta práctica en el oasis y con ello de los arqueólogos como agentes difusores del discurso patrimonial, sentaron las bases para una patrimonialización étnica temprana que venía gestándose desde tiempos de Le Paige. El envío de piezas arqueológicas de oro al Museo Nacional de Historia Natural en Santiago aglutinó a dirigentes locales para reclamar su devolución ante el CMN, situación inédita hasta el momento, así como impulsó un proceso de apropiación local del patrimonio (Ayala 2008). Esto se desarrollaba contemporáneamente al incremento de la actividad turística en San Pedro de Atacama y al comienzo de una mayor intervención del Estado a través del Servicio Nacional de Turismo en la zona.

A nivel nacional se realizaron una serie de movilizaciones sociales para el retorno a la democracia después de casi diecisiete años de dictadura. Entre las poblaciones indí- genas el movimiento mapuche tuvo un rol destacado, aunque no participó como una fuerza fundamental de la oposición, sino como una fuerza autónoma trabajando en coalición con otros, pero manteniendo su propia identidad política (Hale y Millaman 2005). La participación, incluyendo la indígena, se constituyó en uno de los principales emblemas de lucha contra el régimen militar en el discurso oficial utilizado por la coalición de partidos democráticos (Paley 2001). Sin embargo, la discontinuidad y ruptura discursiva en el campo político cimentada en la oposición represión-dictadura/participación-democracia, no significó un cuestionamiento respecto al sistema económico neoliberal implantado durante el gobierno de Pinochet, sino más bien implicó su continuidad y medidas parciales que afianzaron su desarrollo y consolidación.

La reconfiguración del Estado chileno en período democrático va de la mano de la instalación del multiculturalismo neoliberal, lo que genera un nuevo escenario ideológico, legal e institucional orientado a los pueblos indígenas. Con la participación y el reconocimiento de la diferencia cultural como nueva arte de gobierno, la cultura ocupa un lugar central en el debate público y en la construcción identitaria de las poblaciones indígenas y de la nueva nación chilena. En este contexto, la patrimonialización se constituye en un espacio renovado de poder desde el cual el Estado ejerce su poder simbólico de nombrar, autentificar y legitimar las diferencias culturales, el patrimonio y la nación, a la vez que este proceso aporta en la construcción y representación del Estado multicultural. Siguiendo la tendencia iniciada en el período militar, en los primeros años de gobierno democrático se incrementó sustancialmente la declaración de Monumentos Nacionales, así como se diversificaron las categorías seleccionadas y sus lugares de procedencias. Sin embargo, no es sino hasta el segundo gobierno de la Concertación, con Eduardo Frei como Presidente, que se produce una reestructuración del CMN a partir de una verdadera reingeniería de la Secretaría Ejecutiva, la cual pasa de estar encargada de llevar las actas de declaratorias y estar constituida por una persona a asumir una diversidad de funciones y estar compuesta por alrededor de 45 funcionarios. Estas transformaciones se vinculan con la integración de nuevo agentes a este proceso, dentro los cuales destaca la figura del arqueólogo Ángel Cabeza que asume la Secretaría Ejecutiva, 
así como la promulgación de la Ley Indígena y la Ley de Medio Ambiente. A lo que es importante añadir la creciente integración de arqueólogos a esta institución, los cuales se constituyen en especialista del campo burocrático a través de la patrimonialización y conforman la arqueología multicultural.

A esta línea de cambios realizados, no solamente se suma un aumento de las declaraciones de Monumentos Nacionales a lo largo y ancho del territorio nacional, sino que también se diversifica la noción de patrimonio en relación a un discurso de "participación ciudadana". Sin embargo, la definición de esta diversidad patrimonial sigue recayendo en los agentes autorizados por el Estado multicultural a través de sus mecanismos de autentificación y legitimación, los cuales a su vez reproducen los regímenes de verdad impuestos por agencias internacionales como la UNESCO, ${ }^{6} \mathrm{ICOM}^{7} \mathrm{e}$ $\mathrm{ICOMOS}^{8}$ en esta materia. Es decir que a pesar de este discurso participativo del CMN siguen siendo los expertos legitimados por el Estado quienes deciden qué es patrimonio nacional, étnico, salitrero o de derechos humanos. La patrimonialización se constituyó así en un espacio de producción de nuevos métodos de intervención del Estado multicultural ya que, a través de la creación de Consejos Asesores del CMN, se regula y controla a la población local a través de su patrimonio, a la vez que se despliega un dispositivo de territorialización nacional. Esto se lleva a cabo mediante la creación de Consejos Asesores a nivel comunal, provincial o regional, así como con el aumento de Visitadores Especiales a lo largo y ancho del país. Si bien por Ley el Consejo es una institución de carácter centralizado que funciona en Santiago, estas instancias se crearon debido a que "... el Consejo ha enfrentado la necesidad de tener presencia en todo el país y de desconcentrar sus funciones..." (Simonetti 2005: 102). Cada Consejo Asesor se encuentra presidido por la máxima autoridad de la unidad territorial: Intendente, Gobernador o Alcalde. De esta forma, no solamente se usa la distribución (mapeo) y definición

\footnotetext{
${ }^{6}$ United Nations Educational, Scientific and Cultural Organization (Organización de las Naciones Unidas para la Educación, la Ciencia y la Cultura).

7 International Council of Museums (Consejo Internacional de Museos).

8 International Council of Monuments and Sites (Consejo Internacional de Monumentos y Sitios).
}

de los Monumentos Nacionales como una estrategia de territorialización, sino que también el nombramiento de Consejos Asesores va dibujando y marcando los límites espaciales de la nación chilena.

Esto se vincula además con una difusión nunca antes vista del discurso patrimonial autorizado y legitimado por el Estado a través de revistas, libros, postales, poster y su página web, además de la creación del Día del Patrimonio y todo el impacto mediático que este provoca. $\mathrm{Pa}$ ralelamente a lo cual, a diferencia de las décadas previas cuando su control sobre las excavaciones era escaso, la intervención estatal en la práctica arqueológica se fortaleció desde la década de los noventa a través de la regulación de los permisos de investigación y de proyectos de impacto ambiental, a lo que se suma el formato estandarizado para la postulaciones a FONDECYT.

Mostrando de manera concreta la lógica del multiculturalismo neoliberal la reconfiguración del CMN es asociada por sus propios agentes a la Ley de Impacto Ambiental, a partir de la cual no solo se burocratizaron aún más sus normas y procedimientos sino que se ampliaron sus atribuciones, responsabilidades y actividades como órgano de competencia ambiental. El cambio ha sido tan radical en este sentido que de ser un organismo encargado fundamentalmente de la declaración de Monumentos Nacionales, el CMN ha pasado a revisar cientos de casos relacionados con los estudios de impacto ambiental y a funcionar como un mercado que regula los proyectos de inversionistas nacionales o transnacionales. Esta actividad ha repercutido a su vez en la conformación de una arqueología multicultural que ha profundizado aún más su dependencia del campo burocrático, así como ha despolitizado los problemas sociales y económicos asociados a este tipo de proyectos. La racionalidad neoliberal reproducida por los arqueólogos multiculturales no solo se refleja en su cambio de papel de investigador a consultor sino también en su competencia por adjudicarse las mejores ofertas de este mercado y pensar la arqueología como una empresa y a ellos mismos como empresarios. Esto ha generado una división social del trabajo al interior del campo arqueológico entre quienes se dedican a la investigación, los que trabajan en este tipo de proyectos y los que realizan ambas actividades. Asimismo, se han producido disputas de poder por las definiciones de la 
arqueología de contrato y la regulación de honorarios y permisos asociados, lo que impulsó a la Sociedad Chilena de Arqueología a la confección de un código de ética. La despolitización y tecnicismo de la arqueología de impacto ambiental ha derivado en una disociación de los arqueólogos entre sus acciones vinculadas a las poblaciones indígenas o locales y su participación en proyectos de inversión que atenten contra sus derechos. Lo que se relaciona además con la diferenciación que se hace entre una arqueología pública asociada a los proyectos comunitarios de puesta en valor y una arqueología de impacto ambiental como si fueran la expresión de realidades separadas, en circunstancias en que muchas de estas grandes inversiones se han realizado precisamente en territorio indígena.

La privatización de lo que antes se consideraba un ámbito de competencia del Estado también forma parte de la patrimonialización en la era multicultural, tal como se observa en los cambios producidos en el CMN, desde donde se comenzó a gestar el aporte de privados (nacionales e internacionales) para la protección y conservación del patrimonio nacional. Situación en varios casos intermediada por la ejecución de megaproyectos mineros, hoteleros, viales o de otro tipo. Esta misma lógica es la que, en parte, impulsó la apertura del Programa de Patrimonio Mundial para acceder a las fuentes de financiamiento de agencias multilaterales, tales como el Banco Interamericano de Desarrollo (BID en adelante) que hasta el momento ha entregado importantes sumas de dinero para la puesta en valor, conservación, protección o restauración del patrimonio en Chile. La integración de un bien tangible o intangible a la Lista de Patrimonio Mundial es considerada por los organismos internacionales como un factor de desarrollo, discurso también reproducido por el CMN a través de la patrimonialización multicultural a nivel nacional y en términos de etnodesarrollo en territorio indígena. Respecto a los beneficios económicos de este programa Ángel Cabeza dice:

"...la idea de tener estos sitios de patrimonio mundial tenía que, no solamente se buscaba la declaración de estos sitios sino que se buscaba posicionarlos a nivel internacional y buscar de alguna medida la atención a nivel interno y externo desde el punto de vista de recursos. Yo sabía que varios de los Sitios de Patrimonio Mundial lograban tener recursos internacionales por parte del BID y por parte del Banco Mundial, entonces, a poco trecho de la declaración de Chiloé se inicio una solicitud de préstamo al BID por unos 15 o 16 millones de dólares y a poco lograr la declaración de Valparaíso el gobierno solicito también al BID un préstamo por 67 millones de dólares... Los porcentajes son, el país pone el $60040 \%$ o la mitad de la mitad, esa es la figura, y posteriormente el propio Ministerio de Obras Publicas solicitó también al BID un financiamiento de 100 millones de dólares para Monumentos Nacionales en los cuales hay varios de patrimonio arqueológico, si todo se da bien hace 6 meses que andaba detrás de eso..."(Á.C., 2009).

En el caso del Patrimonio Mundial los mecanismos de autentificación y legitimación recaen en agencias estatales e internacionales que difunden un régimen de verdad universalista. En debates internacionales liderados por científicos sociales y representantes de los pueblos indígenas, las listas de sitios postulados al Patrimonio Mundial se consideran como otra forma de control, definición y apropiación del pasado indígena aunque esta vez a nivel global (Scham 2008; Sudharshan 2008). Esto debido a que son los Estados y los organismos internacionales los que definen y legitiman qué es lo que representa "mejor" a una nación determinada y a la humanidad en general, así como porque la designación de Patrimonio Mundial conlleva sobreponer otra forma de propiedad, en este caso universal, sobre la propiedad de los pueblos indígenas, la cual en muchos casos tampoco es reconocida a nivel nacional. Paralelamente a esto, si bien en este programa está en juego una representación de la nación multicultural chilena hacia el exterior, en la cual el monumento elegido sirve como una marca de nacionalidad puertas afuera, con la celebración del Día del Patrimonio se produce un mecanismo inverso ya que se trata de un ritual de ciudadanía nacional puertas adentro.

Así como el CMN en su accionar cotidiano visibiliza, construye y legitima al Estado multicultural, el Día del Patrimonio lo pone en escena y lo produce a través de símbolos y ritualizaciones masivas que representan el poder simbólico del Estado en el arte de nombrar, producir y autentificar lo que es la cultura y el patrimonio de la nueva nación chilena diferencialista. Recordado como uno de los mayores impulsores del Día del Patrimonio, durante una de sus primeras celebraciones, el Presidente Ricardo Lagos destacó la necesidad de 
resaltar los "valores del legado cultural forjado por la historia nacional”, además de plantear que: “...nunca el desarrollo de un país es completo si no hay un avance cultural basado en sus raíces, en su historia y en sus valores, que es lo que nos debe hacer permanecer como sociedad y como nación" (Diario La Hora, 29 de mayo de 2000). Reforzando la efectividad de este mecanismo de construcción de la comunidad nacional chilena, al referirse al éxito del Día del Patrimonio en años posteriores, la Presidenta Michelle Bachelet planteó: "estoy muy contenta y espero que toda la gente que hoy está yendo a distintos lugares, no sólo en la Región Metropolitana, sino a lo largo de todo el país, pueda gozar de aquello que es de todos los chilenos: nuestro patrimonio" (El Mercurio, 25 de mayo de 2008).

Se trata de un evento que actualmente ocupa un rol central de las actividades del CMN y que reproduce una tendencia global en la escenificación, autentificación y legitimación del patrimonio nacional y cuya efectividad como herramienta nacionalizadora y territorializadora ha sido anteriormente probada. A través de la peregrinación anual masiva a monumentos nacionales y edificios públicos los visitantes reactivan su sentido de pertenencia a la comunidad chilena imaginada, así como son llamados a participar simbólica y momentáneamente del poder del Estado a través del recorrido de sus edificios más representativos, como el Palacio de la Moneda a la cual cada año acuden cientos de visitantes. Es así que el Estado multicultural se concretiza y se materializa no sólo a través de monumentos y edificios públicos sino mediante el ritual mismo de "participar" de esta "fiesta de la ciudadanía". En los últimos años se ha comparado al Día del Patrimonio con las fiestas patrias, tal como lo expresó la Directora de la Dirección de Bibliotecas, Archivos y Museos: "Hoy pudimos ver una real fiesta ciudadana. Este día se ha transformado en un segundo 18 de septiembre para todo el país" (El Mercurio, 1 de junio de 2009). Lo cual es reforzado además por uno de los últimos posters alusivos a esta conmemoración, en el cual se reproduce una imagen de las "Fiestas Patrias en Santiago, ca. 1860", que acompaña el slogan de esta décima versión: "La Fiesta del Patrimonio".

En las regiones esta celebración se produce en clave étnica y convoca a las más altas autoridades de la patri- monialización local, quienes en sus discursos y desde su lugar de enunciación legitiman las diferencias culturales promovidas por el Estado multicultural y definen que es el patrimonio indígena. Es así que en San Pedro de Atacama la ceremonia organizada por la Municipalidad y el IIAM el año 2009, estuvo cargada de símbolos y discursos que realzaban el "patrimonio andino" y la importancia de la herencia cultural de "nuestras etnias originarias" y "la participación indígena en el patrimonio". La patrimonialización del pasado indígena en este territorio estuvo orientado por palabras como las del Intendente, Cristian Rodríguez, quien manifestó que junto con conmemorar el "Día Nacional del Patrimonio" se celebra "...el Día del Patrimonio Andino, instancia donde expresamos nuestra valoración más profunda, a las obras y el legado de nuestros pueblos originarios, a nuestros antepasados atacameños, quechua, coyas, aymaras, changos y otros pueblos más". Como parte de esta misma celebración, después de visitar las nuevas oficinas del CMN, el programa del Día del Patrimonio se trasladó al IIAM, el cual fue representado por su director, Mark Hubbe, como un espacio abierto al diálogo, orientado a diversificar sus relaciones con las comunidades atacameñas y a generar espacios de participación.

Por lo simbólico de este evento, no puedo dejar de mencionar el festejo del Día del Patrimonio realizado en el Pukara de Quitor el año 2005. En esta ocasión, la apropiación y nacionalización del pasado indígena se produjo "in situ", en uno de los Monumentos Nacionales más emblemáticos de las disputas patrimoniales atacameñas por el control y manejo de sus recursos culturales (Ayala 2008). El acto central incluyó el uso de símbolos nacionales como la bandera y el escudo chilenos y la presencia de un alto porcentaje de agentes involucrados en el proceso de patrimonialización a nivel local y regional. A lo que se sumaron símbolos andinos como la wiphala y una ceremonia ancestral institucionalizada de pago $\mathrm{u}$ ofrenda de agradecimiento a la tierra por el trabajo realizado a cargo de una "cultora" local. De este modo, este sitio tantas veces demandado como lugar de los "abuelos" o "gentiles" por los atacameños, es nacionalizado el Día del Patrimonio para otorgar una profundidad cronológica -a través de fechados absolu-

\footnotetext{
9 Bandera utlizada por diferentes agrupaciones étnicas en los Andes.
} 
tos- al actual estado multicultural chileno, el mismo que otrora negara un vínculo genealógico con los pueblos indígenas.

Paralelamente a este proceso, desde la promulgación de la Ley Indígena el CMN comenzó a trabajar con la CONADI en diferentes proyectos de administración de sitios, los que en la década de los noventa se centraron en la región atacameña donde se produjo una patrimonialización étnica temprana (Ayala 2008), la cual se constituyó en un nuevo espacio a través del cual gobernar a la población indígena. En efecto, respondiendo a una de sus demandas patrimoniales "aceptables" estas instituciones inician el proceso de catastro, puesta en valor y manejo de sitios arqueológicos, a través del cual se implementan nuevos métodos de intervención estatal. En este contexto, agentes de la política indígena local y nacional, algunos de los cuales forman parte de esta etnia, incitan a los atacameños a participar y a pensar en el desarrollo con identidad a través de la administración de sitios arqueológicos para su integración al próspero mercado turístico y de los bienes exóticos. Se los responsabiliza entonces de su etnodesarrollo mediante el manejo de su patrimonio, a lo cual se suman cursos de capacitación en arqueología y turismo para su profesionalización. Sin embargo, los atacameños no se limitan a ser objetos de gobierno y etnodesarrollo y desde los propios espacios abiertos por la patrimonialización multicultural, cuestionan al Estado y a la arqueología desde adentro disputando la definición, clasificación y propiedad de su patrimonio. Es así que se producen una serie de luchas de poder en torno a los sitios arqueológicos Aldea de Tulor y Pukara de Quitor. Asimismo, con una posición de poder diferente a la de años previos los atacameños confrontaron sus intereses con los de los arqueólogos quienes a la vez quisieron imponer los suyos haciendo uso de su autoridad y lugar de enunciación. Lo cual también se vio atravesado por conflictos al interior del campo arqueológico donde se disputaba la legitimidad de quienes trabajaban en este tipo de proyectos "no científicos". Por su parte, entre las autoridades del poder estatal local, representado por la jefa de la CONADI de Calama (Liliana Cortés) y el poder central, representado por el Director Nacional de la CONADI (Rodrigo Valenzuela) y el Secretario Ejecutivo del CMN (Ángel Cabeza), se debatió sobre la propiedad del patrimonio arqueológico. Mientras la jefa de la CONADI local, des- de su posición de etnoburócrata o "cultural broker", defendió la propiedad indígena del mismo, los burócratas del poder nacional defendieron la propiedad del Estado. Finalmente estos conflictos se llevaron al plano de los tecnicismos y de los "hechos consumados" y posteriormente se apaciguaron las aguas.

Esta fue la tónica de la década de los noventa en la patrimonialización atacameña, la cual se constituyó en un "campo de batalla" por el patrimonio arqueológico a partir de la radicalización de los discursos y las demandas indígenas al Estado y los arqueólogos. Paralelamente a lo cual la respuesta de estos últimos fue "encerrarse en una burbuja de cristal", es decir, focalizarse en sus investigaciones y tomar una postura completamente despolitizada, asumiendo además la autonomía de la arqueología respecto al campo etnoburocrático en construcción. Por su parte, las demandas patrimoniales atacameñas fueron planteadas desde los mismos espacios participativos abiertos por el multiculturalismo (cursos, talleres y seminarios), así como desde otros lugares promovidos por agrupaciones y líderes indígenas considerados "radicales" y generalmente críticos de la CONADI. Esto se desarrolló en un contexto más amplio de acciones concretas en contra de los principales poderes locales: la iglesia, la ciencia y el Estado, a través de actos violentos como el intento de quemar el museo. Este hecho fue especialmente significativo y si bien recibió críticas desde los propios líderes atacameños reflejó el accionar de agrupaciones asimilables al "indio radical insurreccionario", también vinculadas con el atentado a la CONADI y la iglesia, la "toma" simbólica del museo y las oposiciones más críticas a las construcciones hoteleras. Contexto conflictivo desfavorable para el mercado turístico local, nacional e internacional, que requiere más bien al indio permitido/auténtico/cliente exótico que produce y legitima al Estado multicultural chileno como un lugar seguro y beneficiosos para la inversión extranjera. En estas circunstancias, los problemas entre el museo y la población indígena ya no se circunscribían al ámbito local sino que representaban un problema nacional, a la vez que reflejaban los conflictos entre el Estado y sus expertos con las comunidades atacameñas.

A principios del año 2000 se producen cambios importantes en la patrimonialización ya que durante el tercer 
gobierno de la Concertación, con Ricardo Lagos como Presidente, se inaugura el Área de Patrimonio Cultural Indígena en el CMN, así como se declara el Día del Patrimonio por decreto y se impulsa con fuerza el Programa de Patrimonio Mundial. Este gobierno es considerado como un punto de quiebre en relación a la política de la cultura en Chile, no solamente por los cambios mencionados sino también por otros proyectos culturales que pone en marcha y por la discusión que inicia en términos de la legislación e institucionalidad patrimonial. Paralelamente a esto se profundiza la política indigenista $e$ intercultural iniciada en la década de los noventa con la apertura del Programa Orígenes, financiado con fondos del gobierno y del BID, y cuya implementación está directamente vinculada con los propósitos de desmovilizar y apaciguar el conflicto indígena mapuche que había nuevamente recrudecido a fines de la década de los noventa (Bolados 2010: 17). La construcción de la central hidroeléctrica Ralco en territorio pehuenche, específicamente en la región del Bio-Bio, perteneciente a capitales trasnacionales españoles (Endesa), dejó en evidencia las debilidades y contradicciones entre la política indígena y medio ambiental de los gobiernos democráticos, especialmente durante la administraciones de Eduardo Frei y Ricardo Lagos.

En este contexto político se inaugura el Área de Patrimonio Cultural Indígena del CMN, a cargo de César Millahueque, profesional mapuche que asume el rol de nuevo etnoburócrata del campo intercultural y que define este lugar de la patrimonialización como un "no lugar". Desde un principio sus líneas de acción fueron, por un lado, continuar con el proceso de catastro y puesta en valor de sitios arqueológicos iniciado anteriormente en la región atacameña y apoyar la profesionalización indígena a través de la Escuela Andina (vid. infra). Y por otro, poner en marcha el programa de catastro de Complejos Religiosos y Ceremoniales en las Regiones del Bío-Bío (VIII), la Araucanía (IX) y Los Lagos (X). Su apertura sin duda fortalece y profundiza el gobierno de lo étnico a través de la patrimonialización ya que implementa nuevos mecanismos de autentificación y legitimación así como nuevos métodos de intervención del Estado multicultural. Aunque a escala menor esta área del CMN reproduce dispositivos de difusión e instalación del discurso patrimonial a través de folletería, cursos, charlas, talleres y videos, mediante los cuales se produce, autentifica y legitima el patrimonio indígena desde una visión tradicionalista y estereotipada de las diferencias culturales, lo cual a su vez aporta en la construcción del multiculturalismo de Estado. En un folleto del 2007, al definir lo que es participación indígena se menciona que "es muy importante que la comunidad esté informada, es un derecho que las personas participen en la toma de decisiones", planteando además que esta agrupación tiene el derecho de ser escuchada, que "sin la voz de la comunidad no existe participación" ya que solamente con la "participación comunitaria se profundiza la democracia".

Se trata de una labor conjunta del CMN y la CONADI a la que se sumó poco después el Programa Orígenes, cuyos métodos de intervención consisten en trabajar en terreno con las comunidades incitándolas al etnodesarrollo vía proyectos patrimoniales y su profesionalización, proceso que a su vez implica responsabilizarlas por el cuidado y protección de sus bienes patrimoniales, tal como se afirma en folleto antes mencionado: "es obligación de la propia comunidad mantener sus espacios, el Estado en estos casos facilitará asistencia técnica y apoyará vía proyectos de carácter cultural concursables", concluyendo además que "con participación se profundiza democracia". Hasta el 2009, por problemas de presupuesto, el Area de Patrimonio Indígena del CMN focalizó sus acciones principalmente en el norte y sur del país, específicamente en el territorio atacameño y mapuche, aunque cuenta con algunos proyectos en Santiago con indígenas urbanos y otras regiones como Arica y Chiloé. Lo que no deja de llamar la atención sobre todo considerando la persistencia de los conflictos mapuches hasta nuestros días y la gran inversión turística y minera realizada en la región atacameña. A diferencia de los proyectos patrimoniales atacameños, fundamentalmente orientados a los sitios arqueológicos, en territorio mapuche son considerados para su declaración como Monumentos Nacionales los Complejos Religiosos y Ceremoniales de uso histórico y etnográfico, compuestos por nguillatuwe, ${ }^{10}$ menoko, ${ }^{11}$ tre-tren, ${ }^{12}$ eltun ${ }^{13}$ o cementerios $y / 0$ otros elementos.

\footnotetext{
${ }^{10}$ Espacio ceremonial en que se realiza el nguillatun.

${ }^{11}$ Espacio húmedo en el que moran los dueños del agua.

12 Cerros tutelares.

${ }^{13}$ Funerales o cementerios mapuche.
} 
Hasta la fecha ya han sido declarados varios de estos complejos, por lo que la patrimonialización entendida como nacionalización y territorialización materializa y extiende sus efectos en territorio mapuche.

La Escuela Andina es otra de las innovaciones más importantes de este proceso y reproduce a nivel local sus principales características así como las de la arqueología multicultural. En este sentido, aporta tanto en la puesta en escena y producción del Estado multicultural como este último se hace carne y se construye en la cotidianidad de este programa, en sus prácticas y discursos, en sus convenios, en sus informes económicos, en la ritualización de sus ceremonias de apertura y de clausura, en sus dinámicas de postulación y selección, en la relación entre estudiantes y docentes, en su inserción al IIAM y en sus vínculos interinstitucionales. Se trata de un nuevo espacio para gobernar a la población indígena a través de su participación, para regular su conducta en tanto "alumnos" que son responsabilizados por los conocimientos científicos que reciben y por la reproducción y difusión del discurso patrimonial en sus comunidades. Control que también se observa de manera concreta en las listas de asistencia y de postulaciones, en el énfasis en la representatividad de la mayor cantidad de comunidades atacameñas y en los llamados anuales a postular en las reuniones comunitarias y de las Áreas de Desarrollo Indígena. Asimismo, a través de la Escuela Andina se ponen en marcha los mecanismos de autentificación y legitimidad de quién tiene la autoridad de definir lo cultural, lo patrimonial, lo nacional, lo indígena y su pasado. Es un programa creado desde y para la reproducción del conocimiento científico que es el lenguaje autorizado y legitimado del Estado, cuyo poder es reforzado por el lugar de enunciación desde el cual se difunde: el IIAM de la UCN. El poder simbólico de estas instituciones en la producción de la cultura atacameña y su territorialización no solamente es legitimado por el Estado sino por los propios atacameños que hacen uso de dicha producción en sus reivindicaciones étnicas. Tal como se observa en los proyectos que justifican y fundamentan este programa como en su funcionamiento cotidiano, la Escuela Andina aporta en la construcción y reproducción de las diferencias culturales producidas y promovidas por el Estado multicultural a la vez que en la re-imaginación de la nueva nación chilena diferencialista. Proceso en el cual la arqueología multicultural ha tendido a generar una representación "real" o auténtica de la cultura y el territorio atacameño, en circunstancias que esta disciplina tiene el poder de entregar una imagen legítima de su pasado desde que se inicio la arqueología en estos territorios.

En una paradoja propia de la era multicultural, a través del "modelito Escuela Andina" el Estado profesionaliza a los atacameños en su propio conocimiento, es decir, les entrega un certificado que los legitima y autoriza como conocedores de su propia cultura, como dijo un alumno es un programa en el que "te están diciendo lo que tú eres". Ahora bien, siguiendo la lógica del multiculturalismo neoliberal, los objetivos de este programa no solamente apuntan a la difusión del conocimiento científico sino también a su uso como recurso estratégico en el mercado de la cultura, ya que para la CONADI y el Programa Orígenes el indígena capacitado es una herramienta de etnodesarrollo. Según Rodrigo Valenzuela, Encargado de Fortalecimiento de Orígenes:

“...entonces la idea ha sido fortalecer esos otros capitales, vía apoyar Escuela Andina, la escuela de dirigentes, escuelas de base, proyectos para organizaciones, encuentros, lo que llamamos pasantías, donde un grupo de dirigentes va a visitar a otro grupo de dirigentes para que se desarrollen procesos de compartir conocimientos, la evaluación final de todo esto es que a lo largo del país, como por ejemplo la Escuela Andina, ha ido quedando un número interesante de alumnos capacitados por decirlo así, dirigentes más fortalecidos en el sentido que hay un número importante, sólo la Escuela Andina son más de 100 personas, sólo una experiencia dejó más de 150 personas o jóvenes indigenas capacitados en determinados nichos temáticos, ese modelo es una herramienta de desarrollo, un alumno de la Escuela Andina termina su plan y el tipo sabe algo de patrimonio, de arqueología, de historia de su pueblo, como él arme eso ya hace parte de la creatividad de él mismo o el apoyo que le brinde su comunidad, nosotros le entregamos la herramienta y montamos la escuela, se dicta el taller..." (R. V., 2008).

Profesionalizar a los atacameños a través de este programa permite formar gestores, administradores y guías que puedan competir eficientemente en la industria turística, es decir, los ayuda a etnodesarrollarse, a postular y a ejecutar proyectos de rescate cultural y reafirmación identitaria. A la vez que, en conocimiento de la legislación patrimonial, los atacameños pueden responsabilizarse por el cuidado, protección y manejo de su patrimonio, 
aliviando así al Estado de sus obligaciones en esta materia. La eficacia de este programa en el gobierno de lo étnico lo ha posesionado a nivel nacional e internacional como una de las experiencias más exitosas de la política indígena en Latinoamericana y se lo quiere replicar en territorios mapuche y aymara.

Sin embargo, como parte de los efectos no esperados del multiculturalismo, la Escuela Andina también se ha constituido en un espacio de disputa por la autoridad y legitimidad del conocimiento indígena, el cual demanda ser integrado a este programa. Desde el momento de su apertura y hasta su más reciente versión los alumnos han planteado la necesidad de incluir a expertos locales en la Escuela Andina, especificando que dicha participación tiene que ser en igualdad de condiciones a las de los docentes. Asimismo, reconociendo la autoridad y poder del conocimiento científico plantean su derecho a acceder a ese tipo de información que se basa en su cultura, a la vez que ponen en tela de juicio la veracidad y legitimidad de las ciencias sociales a la hora de comparar sus resultados con sus propios conocimientos. A lo cual se suman aquellos atacameños que cuestionan el tipo de participación indígena que se promueve en este programa.

Las controversias y críticas surgidas en dicho diagnóstico sobre el tipo de certificación entregada en este programa también ponen en evidencia que el gobierno étnico no se produce sin disputas en el seno de la patrimonialización. El reclamo de los alumnos por la capacitación que les "adeudaba" la Escuela Andina, tanto por el título que recibían como por las autoridades que firmaban los certificados, demostró que los atacameños quieren contar con las mismas armas de legitimidad del Estado, por lo que sí importa si su certificado los habilita como instructores, monitores o defensores del patrimonio o guías de turismo, así como sí es relevante si el diploma tiene la firma del Director del IIAM y la Jefa de la CONADI o, como ellos quieren, de las autoridades de la UCN. Ciertamente, el hecho de contar con un certificado oficial de esta Universidad, con todos los timbres y firmas que esto implica, les entrega un capital simbólico y social que no tienen por el sólo hecho de ser productores de su cultura $y$, como ellos mismos lo plantean, los acredita y autoriza para proteger y defender su patrimonio contando con un respaldo institucional.
Ahora bien, un nuevo mecanismos de intervención del Estado multicultural a través de la patrimonialización, apunta a la re-construcción y re-imaginación del pasado étnico imponiendo la continuidad cultural como pre-requisito para ser reconocido y legitimado como indígena y por ende acceder a los derechos otorgados por las políticas de la diferencia. Con esto, el gobierno de lo étnico se extiende a las políticas de la memoria indígena ya que el "indio auténtico" debe demostrar una continuidad cultural de larga data posible de rastrear hasta tiempos precolombinos. Proceso en el cual el Estado, como instancia central de nombramiento, autentifica y legitima a los arqueólogos, entre otros profesionales, como expertos de esta producción y definición de autenticidad. Rol que por lo demás es reclamado por los propios arqueólogos a la hora de evaluar la legitimidad de ciertas agrupaciones catalogadas como "inauténticas" por ser claramente "inventadas" y "recientes". No obstante, las poblaciones indígenas no se limitan a ser gobernadas a través de esta nueva construcción lineal de su temporalidad ya que más bien se apropian y utilizan estratégicamente este discurso para validarse y legitimarse ante el Estado y así desplegar sus propias agendas y demandas. En el caso atacameño, este discurso continuista, construido por lo demás por los arqueólogos, aportó en su inclusión a la Ley Indígena y con ello en su reconocimiento legal ante el Estado chileno, con lo cual accedieron a una serie de recursos, espacios y derechos propios del multiculturalismo de Estado (Ayala 2007 y 2008). Desde su agrupación a nivel étnico, la re-elaboración y construcción del pasado que están haciendo las comunidades atacameñas del salar de Atacama y la cuenca del Loa, es sin duda un proceso en plena construcción, con tensiones y contradicciones entre las nociones de ancestralidad y temporalidad preexistentes y las que impone el multiculturalismo, en un contexto en el que se identifican diferentes juegos de identidades y temporalidades aún operando. El cambio que se observa en los discursos referidos a los "Abuelos", que pasaron de ser "otros" a "nosotros", sin duda muestra el proceso de rupturas y continuidades del pasado indígena iniciado con la colonización y seguido por los Estados monoculturales y multiculturales.

Este ejercicio del poder que se ejerce a través de la memoria indígena se vincula además con el gobierno de los cuerpos, pero esta vez, a diferencia de lo que ocurre en 
el campo de la salud desde donde la gubernamentalidad se ejerce sobre el cuerpo individual y colectivo de la población indígena, se la regula a través del cuerpo de sus ancestros. En este contexto, el Estado ha diversificado aún más sus espacios y mecanismos de regulación en la era multicultural ya que sigue siendo desde su poder de nombramiento que se define quien está autorizado y legitimado a reclamar a los "restos humanos" como ancestros, quien puede estudiarlos, exhibirlos, conservarlos, colectarlos, excavarlos o re-enterrarlos. El poder que ejercimos como profesionales del IIAM a lo largo del proceso de re-localización de los cuerpos humanos de la exhibición, para reafirmar la decisión institucional de "cambiarlos de lugar en el mismo museo" sin dar pie a mayores discusiones sobre su re-entierro o devolución, es sin duda una muestra del poder simbólico del Estado en el acto de nombrar y de la arqueología de reproducir su autoridad y lugar de enunciación. Si bien el retiro de los cuerpos de las exhibiciones ha sido últimamente una de las demandas indígenas más aceptadas de parte de los arqueólogos y el Estado, la demanda de re-entierro que tanto se trató de silenciar en las reuniones de la mesa de trabajo, recientemente está siendo considerada "aceptable" específicamente para hallazgos arqueológicos nuevos. De este modo, el Estado se asegura el control y regulación de los cuerpos humanos depositados hasta la fecha en los museos estatales y privados desde que se inició la arqueología en el país. Así, gobernando a la población indígena a través de la regulación de los cuerpo de sus ancestros y realizando algunos re-entierros en la zona atacameña y aymara (con su correspondiente proceso burocrático y científico y su ritualización), el Estado multicultural chileno se pone en sintonía con la tendencias de la museología a nivel mundial y con ello se representa como una nación respetuosa de las diferencias culturales que lo conforman. ${ }^{14}$

El análisis de las reuniones para el retiro de los cuerpos de la exhibición del IIAM, evidencia que estos espacios de participación restringida abiertos por esta institución en la era del multiculturalismo neoliberal, también fueron apropiados y utilizados por los atacameños para cuestionar el tipo de participación impuesta y el poder de

\footnotetext{
${ }^{14}$ Una de las instituciones que está difundiendo globalmente la Ley NAGPRA de repatriación y re-entierro es el Museo Nacional del Indígena Americano del Smithsonian, a cargo del cual se realizaron los primeros procesos de este tipo en Chile.
}

decisión del museo, así como para visibilizar las relaciones coloniales de negación de lo indígena que siguen operando en esta institución. Por ello, la carta presenta por el líder atacameño, Carlos Aguilar, al grupo de trabajo, en la cual solicitó información detalla sobre las colecciones del museo, su lugar y año de excavación y los responsables de las mismas, no hizo otra cosa que proponer al IIAM "desclasificar" la epistemología colonial de desconectar las colecciones de su historia. Desclasificación que para Vezub (2009: 3-4) consiste en "conectar a los restos con su historia, invirtiendo el trabajo de campo (...) y concebir al museo como el terreno arqueológico para desandar una historia y una historiografía".

\section{* La arqueología multicultural: UN EJERCICIO DE REFLEXIVIDAD AUTOBIOGRÁFICA}

Para situar y analizar mi práctica profesional al interior de la patrimonialización recién expuesta, en este subtítulo presento una reflexión sobre mi rol como arqueóloga en San Pedro de Atacama, centrándome en mi papel como Coordinadora del programa de educación patrimonial Escuela Andina y de la Unidad de Relaciones con la Comunidad Atacameña del IIAM. Me focalizo en un lugar y tiempo determinados, en una micro-historia reciente contada desde mi perspectiva como agente -individual y colectivo- en la conformación de una "arqueología multicultural". Asimismo, estableciendo una conversación entre este ejercicio reflexivo y los aportes de las teorías arqueológicas descolonial, indígena y relacional, discuto las principales características de este tipo de arqueología en Atacama.

Llegué a vivir a San Pedro de Atacama el año 2002 en un contexto de cambios del multiculturalismo neoliberal en Chile, ya que se dejaron de enfatizar los discursos de negación y conflicto por otros de inclusión, diálogo, negociación y consenso. Como vimos en páginas previas, este giro hacia una retórica más dialógica de parte del Estado chileno no solo repercutió en la política indígena nacional sino también en la patrimonialización del siglo XXI al crearse un discurso de "participación ciudadana” en el CMN. A nivel disciplinario, me encontré con un IIAM en proceso de transformación, no solamente en cuanto al cambio de Director sino también en términos de sus relaciones con la comunidad indígena local. El 
intento de incendiar el museo llevó a sus autoridades a considerar la importancia de re-orientar las relaciones con los atacameños, quienes entre otros temas demandaban el acceso a la información generada por las investigaciones y su inclusión en el quehacer museológico y arqueológico (Ayala 2008). Tomando como ejemplo las mesas de diálogo creadas por el gobierno para abordar problemas de derechos humanos, el Director de ese entonces, Agustín Llagostera, convocó a los líderes étnicos a una mesa de diálogo. Asimismo, gracias al financiamiento de la CONADI y el CMN se concretó el proyecto de educación patrimonial Escuela Andina.

Ese mismo año comencé a trabajar como uno de los docentes del curso de arqueología de este programa y el 2003 asumí su Coordinación. Lo que coincidió con una etapa de cambios en mi práctica profesional, ya que después de varios años de investigar la prehistoria tardía de la región atacameña, comencé a estudiar las consecuencias sociales de la arqueología y su vínculo con su contexto político e histórico de producción. Paralelamente a esto, junto a otros colegas desarrollé el proyecto "Vinculaciones entre una Arqueología Social y la Comunidad Indígena de Ollague", en los marcos del cual realizamos cursos de capacitación y un encuentro de discusión sobre patrimonio. Acciones basadas en la idea de que el aspecto social de nuestra disciplina debía centrarse en la socialización de las interpretaciones arqueológicas.

Si bien inicialmente la creación de la Escuela Andina tuvo como objetivo principal difundir el conocimiento científico, sus repercusiones a nivel institucional fueron decisivas en la conformación de un discurso de participación indígena al interior del IIAM. El cual poco a poco se fue articulando más estrechamente con la política indígena del multiculturalismo de Estado. Por otro lado, la apertura de este programa, que funciona 9 meses al año, con clases los fines de semana y un cupo de 25 alumnos, generó una serie de expectativas y demandas de parte de las comunidades locales. El curriculum docente ofrecido por esta Escuela, fue visto por los atacameños como una oportunidad de acceder a los conocimientos científicos y una vía de capacitación para mejorar sus oportunidades de trabajo. ${ }^{15}$

\footnotetext{
${ }^{15}$ Los cursos ofrecidos en este programa son: gestión cultural, administración y turismo, legislación, etnoecología, arqueología, historia, antropología, conservación y formulación de proyectos.
}

Dos años después de inaugurar la Escuela Andina, considerando sus beneficios en el "cambio de imagen" del museo al interior de la comunidad local y la demanda de participación indígena en el quehacer arqueológico, se creó la Unidad de Relaciones con la Comunidad Atacameña, uno de cuyos principales objetivos era ejecutar anualmente la Escuela Andina y gestionar fondos externos para su realización. Además de encargarse de realizar charlas sobre arqueología y patrimonio, promover instancias de conversación y negociación, así como participar en reuniones y actividades organizadas por las comunidades atacameñas. El año 2004 asumí la Coordinación de esta área y continué con la dirección de la Escuela Andina y mi docencia en este programa. A continuación abordaré dos aspectos de mi práctica en estos cargos: la construcción del discurso participativo y la reafirmación del lugar de enunciación de la arqueología.

\section{* El discurso de la participación atacameña}

Desde sus inicios la Escuela Andina y la Unidad de Relaciones con la Comunidad Atacameña del IIAM han reproducido los principales lineamientos de la política indígena estatal. Un análisis de sus discursos oficiales evidencia que en actos públicos y actividades institucionales ambas instancias se presentan como espacios de diálogo y participación, que cuadran muy bien con la retórica del multiculturalismo neoliberal, especialmente con aquella vinculada a la tan postergada inclusión de los pueblos indígenas como interlocutores válidos ante el Estado y la sociedad. Sin embargo, una evaluación de sus prácticas y discursos pone en evidencia la reproducción de una participación restringida y controlada a través de la cual se gobierna a las poblaciones indígenas.

El discurso institucional, repetido en diferentes eventos públicos por autoridades del museo y mi persona, mostró el objetivo de "vinculación étnica" como algo muy central a nivel institucional, lo que no se condecía con los recursos aportados por el museo para la Escuela Andina, que funcionaba con fondos externos, ni con el escaso financiamiento otorgado a la Unidad de Relaciones con la Comunidad Atacameña. Estas fueron las palabras del entonces director del IIAM, Agustín Llagostera: 
"(El IIAM) ha apostado a una apertura institucional de la academia hacia las comunidades étnicas, queriendo romper el retrógrado principio de utilizar a las comunidades como objetos de estudio; por lo contrario, queremos estudiar y trabajar junto con ellas, traspasándoles conocimientos que les sirvan para reforzar su identidad y darles argumentos para la valorización de su cultura. En este momento, al estar inaugurando la $3^{a}$ versión de la Escuela Andina, nuestra apuesta nos señala que estamos jugando a ganadores. Los hechos nos muestran que no nos hemos equivocado al abrir las puertas de nuestro Instituto a la comunidad. De esta apertura está surgiendo una riquísima e interesante interacción de la cual todos estamos aprendiendo y creando un modelo de convivencia intercultural. De todo el quehacer con las comunidades, sin duda lo que nos llena de orgullo y satisfacción es la Escuela Andina; orgullo que compartimos con otros organismos gracias a los cuales esta hermosa iniciativa se pudo concretar: Consejo de Monumentos Nacionales, Corporación Nacional de Desarrollo Indígena, y ahora se nos agrega el Programa Orígenes, que se asocia con nosotros en el patrocinio de esta escuela...Incentivando una participación étnica más activa y compatibilizando su desarrollo con los requerimientos de la sociedad mayor, capacitando en la formulación, identificación y ejecución de proyectos relativos al patrimonio, e intentando cicatrizar la tradicional brecha que separa las comunidades étnicas de la ciencia y de la academia" (A. LL., inauguración Escuela Andina 2004).

Asimismo, describimos la interacción con las comunidades indígenas en términos más horizontales y dialógicas de lo que eran en la práctica, ya que en lo concreto los atacameños participaban como alumnos de la Escuela Andina sin mayor acceso a los proyectos científicos del museo. A esto se suma que la condición de alumnos no habilitó a los atacameños que participaban de la Escuela Andina a formar parte de la toma de decisiones sobre este programa ni respecto a las colecciones resguardadas por esta institución. Este fue el discurso que realicé en la certificación de los alumnos el año 2005:

"La historia de la Escuela Andina se remonta a cuatro años atrás, cuando la importancia de fortalecer relaciones entre las comunidades indígenas, los cientificos y las instituciones universitarias y estatales se constituyó en una meta fundamental para estos actores sociales. Se trata de una escuela en la cual el conocimiento local interactúa con el conocimiento científico. Un proceso de aprendizaje mutuo entre docentes y alumnos, de preguntas y respuestas que nos enriquecen día a día, de perspectivas que muchas veces aparecen como irreconciliables y que incrementan el saber de estudiantes y profesores. Es un espacio de encuentro entre personas de identidades diversas, un lugar donde atacameños y quechuas interactúan con personas de otros sectores del país que decidieron quedarse y desarrollar trabajos tan diferentes como el turismo, la docencia, la investigación y otro tipo de oficios. Para quienes trabajamos en el museo, la Escuela Andina es un espacio de construcción de relaciones, de certificación, de valorarse y de respetarse mutuamente..." (P.A., Certificación Escuela Andina 2005).

Este contexto, bajo el "encanto multicultural" aportamos a la construcción de un discurso que generó la idea de que los atacameños habían sido completamente incluidos en el quehacer del museo y que se vivía un verdadero vuelco en nuestras relaciones. Por su parte, a través de la patrimonialización los agentes del Estado, apoyados en la legalidad vigente, generaron la percepción de que los pueblos indígenas sí participan en la toma de decisiones referentes a su patrimonio y su cultura. En estas circunstancias, la Escuela Andina se constituyó en una herramienta de control y fiscalización de la participación y la conducta indígena, ya que a partir de este programa se reguló su integración al museo y sus derechos sobre el patrimonio que alberga.

La reproducción de este discurso más inclusivo también estuvo atravesada por mi investigación acerca de este tema, ya que después de analizar el largo período de vínculos de negación desde la arqueología y el museo de San Pedro de Atacama, planteé la existencia de nuevas forma de relacionamiento con los atacameños a partir del año 2001, materializadas en la diversificación de relaciones de conocimiento mutuo, diálogo, negociación, colaboración e intermediación (Ayala 2007 y 2008). Asimismo, las definiciones de la Escuela Andina que entregué en mis discursos, se encontraban influenciadas por los postulados de la "arqueología social" que desarrollé con otros colegas en Ollague, así como por una perspectiva de la "arqueología pública" en términos de la difusión de conocimientos científicos. En este sentido, interpreté a la Escuela Andina como un ejemplo de relaciones de conocimiento, colaboración y diálogo, así como definí a la Unidad de Relaciones con la Comunidad Atacameña como un espacio de mediación (Ayala 2007 y 2008). De esto modo, visualicé la participación indígena generada a través de la Escuela Andina como un cambio rotundo 
desde los vínculos históricos de negación. Sin embargo, se produjo una disociación entre este discurso más inclusivo y las prácticas concretas de participación, es decir, el accionar cotidiano de este programa dentro el museo. Si bien la creación de la Escuela Andina conllevó una apertura institucional sin antecedentes previos, al no evaluar la coherencia entre nuestros discursos y acciones de relacionamiento con los atacameños, aportamos a la reproducción del discurso multicultural de la "participación sin participación" (Bolados 2010).

Además, al no existir una política étnica en el museo, a pesar de la creación de la Unidad de Relaciones con la Comunidad Atacameña y de los intentos de crearla a través de un taller interno, no se contó y no se cuenta aún con lineamientos que orienten e integren los enfoques arqueológicos conservadores y críticos que coexisten en la institución. Por ello, no existe una congruencia entre el discurso y la práctica sobre los vínculos con las comunidades étnicas al interior del IIAM. A lo que es importante añadir que la dependencia económica estatal de la Escuela Andina atenta contra la construcción de una relación realmente colaborativa entre el museo y los atacameños, ya que, a fin de cuentas, la Escuela Andina debe su existencia a su encuadre cotidiano con la política multicultural.

\section{* La arqueología y la reproducción DE SU LUGAR DE ENUNCIACIÓN}

A través de la Escuela Andina se valida el lugar de enunciación del discurso científico, más aún considerando que los cambios realizados en el programa a lo largo de su historia de nueve años, no han hecho otra cosa que reafirmar el poder de la ciencia y el Estado. Si bien los atacameños han planteado la necesidad de integrar "cultores locales", hasta la fecha esta demanda no ha sido considerada por las instituciones vinculadas en los términos propuestos por los líderes étnicos. En el caso particular de la arqueología, a través de mi práctica docente inicialmente reproduje y legitimé el discurso y autoridad científica de esta disciplina, al asumir que con la sola difusión de este conocimiento establecía relaciones de cercanía, diálogo y colaboración con los atacameños (Ayala 2007 y 2008). Lo que se vinculaba a su vez con mis definiciones, en ese entonces, de la arqueología so- cial y la arqueología pública, las cual apuntaban a la divulgación como un medio de integración y participación de los pueblos indígenas.

"Desde hace unos tres años y en relación al cargo que ocupo he estado desarrollando un trabajo dentro de lo que se conoce como arqueología pública, es decir, una línea de trabajo que desde la arqueología ve la relevancia de difundir los resultados de las investigaciones arqueológicas a la comunidad local, así como también ver los intereses o percepciones de las comunidades cercanas en relación a la reconstrucción del pasado" (P.A., $3^{\text {a }}$ Mesa de Diálogo 2005).

Desde esta perspectiva, tanto en las clases como en las salidas a terreno reproduje las principales interpretaciones de la arqueología atacameña, sin cuestionar su poder como voz autorizada sobre el pasado indígena, aunque en algunas discusiones con los alumnos abrí el debate sobre el principal lugar de enunciación de este discurso: el museo de San Pedro de Atacama.

Sin embargo, así como las definiciones de la arqueología pública y social han ido cambiando, mi práctica como docente de la Escuela Andina transitó de un modelo de comunicación unidireccional y vertical a otro más horizontal en mi último año de docencia, ya no del curso de arqueología sino del de cultura andina, lo que se relacionó con una mayor familiaridad de mi parte con los planteamientos de las arqueologías postcolonial e indígena. En este contexto, en mis clases busqué descentrarme del lugar de enunciación disciplinario y problematizar la autoridad del discurso arqueológico en la definición y validación de identidades étnicas ante el Estado, además de discutir sobre las definiciones de cultura andina construidas desde la arqueología y la antropología.

Dicha experiencia me permite afirmar que si bien la difusión del conocimiento científico ha sido un aporte en la construcción de nuevas relaciones con las comunidades indígenas en Atacama, la reproducción de las interpretaciones arqueológicas sin cuestionar su poder, el lugar desde donde se enuncian y cómo se hace, replica las mismas desigualdades y negaciones que el Estado multicultural mantiene con estas poblaciones. Conformando así una "arqueología multicultural", es decir, una arqueología tradicional ajustada a los mandatos del multiculturalismo neoliberal y su política de participación 
étnica restringida, la cual a su vez valida el poder y lugar de enunciación disciplinario.

La práctica desarrollada por otros docentes de la Escuela Andina también contribuye a legitimar la "arqueología multicultural". En circunstancias que hacer clases en este programa se ha convertido en una forma de seguir practicando un tipo de arqueología que -en el aula y en el proceso investigativo-, escasamente cuestiona o confronta su lugar de enunciación y las relaciones de poder en las que se encuentra inmersa esta disciplina. A lo que se suma que existe una disociación entre la difusión del conocimiento científico hacia las comunidades a través de la Escuela Andina y el quehacer arqueológico, en la cual algunos arqueólogos siguen tomando todas las decisiones sobre el estudio, interpretación y manejo del pasado y el patrimonio atacameño. Según Marcos (2010: 155) en la Escuela Andina "la vinculación con la comunidad se ha limitado al dictado de clases en el espacio educativo, y con este único acto, muchos investigadores han considerado suficientemente abordada la dimensión social de la arqueología".

Esta falta de congruencia entre el discurso y la práctica arqueológica ha sido criticada por alumnos y dirigentes étnicos en diferentes reuniones convocadas por la Escuela Andina y la Unidad de Relaciones de la Comunidad Atacameña en el museo. Estas son las palabras de un estudiante y ex Presidente del Consejo de Pueblos Atacameños, Wilson Galleguillos, entrevistado en el marco del Diagnóstico de Seguimiento y Evaluación de este programa:

“...porque por un lado tenemos Escuela Andina y sin embargo los mismos profesionales están haciendo informes en contra de las comunidades indígenas, en contra de la cultura atacameña, entonces creo que estamos mal...entonces ahí dije que no había consecuencia, por un lado los profesores dijeron estar con las comunidades indígenas sin embargo están haciendo estudios de impacto ambiental eh, favoreciendo a un privado o a un tercero, entonces esto yo creo que es un daño enorme que se le hace al pueblo atacameño... (W.G. 2005).

Como se puede observar, la apertura de este espacio de participación restringida materializada en la Escuela Andina, también ha sido contestada y utilizada por los atacameños para plantear sus propios intereses, de- mandas y críticas a esta institución, sus profesionales y al Estado. Por su parte, algunos alumnos destacan los efectos positivos de este programa en términos políticos y de acceso a información, así como otros hacen un llamado a integrar la Escuela Andina pues dicen que los "atacamaños son los actores principales de este proceso", observándose así una vez más los efectos inesperados del multiculturalismo.

A través de este ejercicio de reflexividad autobiográfica he querido mostrar cómo se entretejieron mis recorridos personales con la historia institucional y el contexto sociopolítico en el cual me desenvolví como arqueóloga en San Pedro de Atacama. Lo que da cuenta del carácter político, económico y sociológico de mi practica arqueológica en un tiempo y lugar específicos. Evidencia, además, los cambios en mi postura frente al multiculturalismo, ya que deja entrever cómo mi concepción inicial sobre las políticas de la diferencia, al considerarlas como una respuesta a la historia de dominación de las poblaciones indígenas, repercutió en mis prácticas y discursos como Coordinadora de Escuela Andina y de la Unidad de Relaciones Comunitarias. Así como influenció en mis definiciones de los aspectos sociales de la arqueología y las líneas de acción adoptadas para construir nuevas relaciones con los atacameños.

Esta micro historia pone al descubierto también las dificultades de articular propuestas teóricas con prácticas concretas. Así como evidencia los problemas enfrentados al tratar de reorientar una historia de relaciones de negación, desde enfoques que no cuestionan el poder y lugar de enunciación de la arqueología y su estrecha relación con el Estado. Evidentemente, transitar desde una práctica históricamente colonialista a otra que se haga cargo de esta herencia y busque revertirla, no es una tarea fácil. Requiere un proceso reflexivo conjunto entre arqueólogos, indígenas y otros interesados en el pasado y el patrimonio cultural, así como el desarrollo de una conciencia vigilante frente al "encanto multicultural", ya que hasta el momento este último ha impulsado solo un "deber ser" en la arqueología en San Pedro de Atacama, la cual ha reproducido un lógica de la "participación indígena sin participación" más que una descolonización disciplinaria y una transformación de sus relaciones con los atacameños. 


\section{* A modo de cierre o apertura}

En esta investigación he querido demostrar cómo la arqueología multicultural ha reproducido la lógica de la "participación sin participación" o "participación impuesta" del multiculturalismo neoliberal en Chile. La diversificación y cambio de las relaciones entre arqueólogos y atacameños observada desde principios del siglo XXI, al estar articulada con los espacios y mecanismos estatales a través de los cuales se gobierna a las poblaciones indígenas, no es la expresión de una re-configuración disciplinaria que cuestione y se haga cargo de su herencia colonial, sino más del ajuste de cintura de una arqueología tradicional acomodada a los mandatos del multiculturalismo. Es el reflejo del deber ser que se ha impuesto como discurso oficial en la arqueología atacameña y que ha impulsado a los arqueólogos a ampliar los circuitos de circulación de su discurso y a integrar a los indígenas parcialmente en sus proyectos. Sin embargo, esta dependencia de los espacios de participación y de las agendas estatales no ha permitido a arqueólogos e indígenas generar relaciones de colaboración autónomas construidas a partir de una reflexión conjunta y sostenida en el tiempo. Por ello, mi propuesta es apostar por una arqueología reflexiva que, recogiendo los aportes de las arqueologías crítica, postcolonial, indígena y relacional, busque desnaturalizar la práctica arqueológica, desenmascar su proceso y condiciones de producción, reflexionar sobre las asimetrías sociales y económicas que la originaron y la siguen produciendo, cuestionar su autoridad científica y lugar de enunciación y concebirla como el estudio del poder y no sólo del estudio del pasado, es decir, hacer una arqueología "de otra manera" con y para las poblaciones indígenas y no a pesar de ellas.

Agradecimientos A Guillaume Boccara y Cristobal Gnecco, directores de mi tesis de doctorado.

\section{* Referencias citadas}

ANDERSON, B. 2007. Comunidades Imaginadas: reflexiones sobre el origen y la difusión del nacionalismo. Fondo de Cultura Económica, México D.F.

ATALAY, S. 2006. Indigenous Archaeology as decolonizing practice. American Indian Quarterly 30 (3 y 4): 280-310.

AYALA, P. 2007. Relaciones entre atacameños, arqueólogos y Estado en Atacama. Estudios Atacameños 33: 133-157. 2008. Políticas del pasado: indígenas, arqueólogos y estado en Atacama. Línea Editorial IIAM / Universidad Católica del Norte, San Pedro de Atacama.

BOCCARA, G. 2007. Etnogubernamentalidad. La formación del campo de la salud intercultural en Chile. Chungará 39(2): 185207

BOCCARA, G. y P. AYALA. 2011. Patrimonializar al indígena: Imaginación del multiculturalismo neoliberal en Chile. Les Cahiers des Ameriques Latines 67: 207-230.

BOCCARA, G. y P. BOLADOS. 2010. ¿Qué es el multiculturalismo? La nueva cuestión étnica en el Chile neoliberal. Revista de Indias 70(250): 651-690.
BOLADOS, P. 2010. Neoliberalismo multicultural en el Chile democrático: gubernamentalizando la salud atacameña a través de la participación y el etnodesarrollo. Tesis de doctorado en Antropología. Universidad Católica del Norte - Universidad de Tarapacá, San Pedro de Atacama.

BOURDIEU, P. 1997. Razones prácticas. Sobre la teoría de la acción. Editorial Anagrama, Barcelona.

BOURDIEU, P. y L. WACQUANT. 1992. An invitation to reflexive sociology. The University of Chicago Press, Chicago.

BRIONES, C. 2005a. (Meta) cultura del Estado nación y estado de la (meta) cultura. Editorial Universidad del Cauca, Popayán.

2005b. Formaciones de alteridad: contextos globales, procesos nacionales y provinciales. En Cartografias argentinas. Politicas indigenistas y formaciones provinciales de alteridad, C. Briones (Ed.), pp.1143. Antropofagia, Buenos Aires.

CASTAÑEDA, Q. y CH. MATTHEWS (Eds.). 2008. Ethnographic Archaeologies: reflections on stakeholders and archaeological practices. Altamira Press, Lanham.

DÍAZ-ANDREU, M. 2001. Nationalism and archeology. Nations and nationalism $7(4): 429-440$. 
FERGUSON, J., y A. GUPTA. 2005. Spatializing states: toward an ethnography of neoliberal governmentality. En Anthropologies of modernity: Foucault, governmentality, and politics of life, J. Inda (Ed.), pp. 105-131. Blackwell Pub, Malden, MA.

FOUCAULT, M. 1992. El orden del discurso. Lección inaugural pronunciada en el Collège de France el 2 de diciembre de 1970. Tusquets, Buenos Aires.

2006. Governmentality. En The anthropology of the state, J. Ferguson y A. Gupta (Eds.), pp. 131-143. Blackwell Publishing, USA, UK, Australia.

GELLNER, E. 1983. Naciones y nacionalismos. Alianza Universitaria, Madrid.

GNECCO, C. 2002. La Indigenización de las arqueologías nacionales. Convergencia 27: 133-149.

2008. Discursos sobre el otro. Pasos para una arqueología de la alteridad étnica. Colombia 2: 101-129.

GUPTA, A. y J. FERGUSON. 1997. Culture, power, place: ethnography al the end of an era. En Culture, power, place: explorations in critical anthropolog, A. Gupta y J. Ferguson (Eds.), pp. 1-27. Duke University Press. Durham and London.

HABER, A. 2004. Arqueología de la naturaleza/naturaleza de la arqueología. En Hacia una arqueología de las arqueologías sudamericanas, A. Haber (Ed), pp. 9-31. Centro de Estudios Socioculturales e Internacionales, Universidad de los Andes, Bogotá.

HALE, C. 2002. Does multiculturalism menace? Governance, cultural rights and the politics of identity in Guatemala. Journal of Latin American Studies 34: 485-524.

HALE, C. y R. MILLAMAN. 2005. Cultural agency and political struggle in the era of the 'indio permitido'. En Cultural Agency in the Americas, D. Sommer (Ed.), pp. 281-304. Duke University Press, Durham y London.

HOBSBAWM, E. 1992. Naciones y nacionalismos desde 1780. Editorial Crítica, Barcelona.

HOBSBAWM, E. y T. RANGER (Eds.). 2002 La invención de la tradición. Editorial Crítica, Barcelona.

HODDER, I. 1991. Interpretative Archaeology and Its Role. American Antiquity 56(1): 7-18.

KOHL, P. 1998. Nationalism and archaeology: on the Constructions of Nations and the Reconstructions of the Remote Past. Annual Review Anthropology 27: 223-46.
LILLEY, I. 2008. Archaeology, the World Bank, and postcolonial politics. En Archeology and the postcolonial critique, M. Liebmann y U. Rizvi (Eds.), pp. 141-164. Altamira Press, New York.

LONDOÑO, W. 2003. Historia social de la arqueología colombiana: la confusión de nacionalismo con modernidad. En Arqueología al desnudo: Reflexiones sobre la práctica disciplinarian, C. Gnecco y E. Piazzini (Eds.), pp. 153-181. Editorial Universidad del Cauca, Serie Estudios Sociales, Popayán.

MARCOS, S. 2010. La arqueología bajo la perspectiva de la comunicación: estudio de caso en San Pedro de Atacama. Tesis de Magister. Universidad Católica del Norte- Universidad de Tarapacá, San Pedro de Atacama.

MITCHELL, T. 2006. Society, economy, and the state effect. En The anthropology of the state a reader, A. Sharma y A. Gupta (Eds.), pp. 169-186. Blackwell Publishing, USA, UK, Australia.

PALEY, J. 2001. Marketing Democracy. Power and Social Movement in PostDictatorship Chile. University of California Press, Berkeley y Los Angeles.

PREUCEL, R. y C. CIPOLLA. 2008. Indigenous and postcolonial archaeologies. En Archeology and the postcolonial critique, M. Liebmann y U. Rizvi (Eds.), pp. 129-140. Altamira Press, New York.

ROMERO, A. 2003. Arqueología y pueblos indígenas en el extremo norte de Chile. Chungará 35(2): 337-346.

SHANKS, M. y C. TILLEY. 1987. Reconstructing Archeology. Cambridge University Press, Cambridge.

SCHILD, V. 2000. Neo-liberalism's new gendered market citizens: the civilizing dimension of social programmes in Chile. Citizenship Studies 4(3): 275-305.

SIMONETTI, S. 2005. El Consejo de Monumentos Nacionales, En Primer Seminario Minería y Monumentos Nacionales, G. Fernández y P. Gonzáles (Eds.) pp. 98-104. MINEDUC-CMN Santiago.

SCHAM, S. 2008. Disinheriting Heritage: Explorations in the Contentious History of Archeology in the Middle East. En Archeology and the postcolonial critique, M. Liebmann y U. Rizvi (Eds.), pp. 165176. Altamira Press, New York.

SUDHARSHAN, S. 2008. Situating World Heritage Sites in a Multicultural Society: the Ideology of Presentation at the Sacred city of Anuradhapura, Sri Lanka. En Archeology and the postcolonial critique, M. Liebmann, U. Rizvi (Eds.), p. 177-195. Altamira Press, New York.

TRIGGER, B. 1984. Alternative archaeologies: Nationalist, Colonialist, Imperialist. Man New Series 19(3): 355-370. 
TRONCOSO, A., D. SALAZAR y D. JACKSON. 2008. Ciencia, Estado y Sociedad: retrospectiva crítica de la arqueología chilena. Arqueología Suramericana 4(2): 122-145.

VEZUB, J. 2009. Henry de La Vaulx en Patagonia (1896 - 1897): la historicidad escindida de la antropología colonial y la captura de corpus y cuerpos. Nuevo Mundo Mundos Nuevos. En http://nuevomundo.revues.org/57810. Consultado el 18 febrero 2011.
WATKINS, J. 2000. Indigenous Archaeology: American Indian values and Scientific Practice. Altamira Press, Walnut Creek.

ZIMMERMANN, L. 2001. Usurping Native American Voice. En The future of the past: Archaeologists, Native Americans, and repatriation, T. Bray (Ed.), pp. 169-184. Garland Publishing, New York y Londres. 